\title{
A Highly Sensitive and Selective Spectrofluorimetric Method for the Determination of Vanadium at Pico-Trace Levels in Some Real, Environmental, Biological, Soil and Food Samples Using 2-( $\alpha$-Pyridyl)-Thioquinaldinamide
}

\author{
M. Jamaluddin Ahmed ${ }^{1 *}$, Ayesha Afrin ${ }^{1,2}$, Yasmin Akhtar ${ }^{1}$ \\ ${ }^{1}$ Laboratory of Analytical Chemistry, Department of Chemistry, University of Chittagong, Chittagong, Bangladesh \\ ${ }^{2}$ Department of Applied Chemistry and Chemical Engineering, University of Chittagong, Chittagong, Bangladesh \\ Email: *pmjahmed55@gmail.com, ayeshaafrin@gmail.com, yasminakhtar470@gmail.com
}

How to cite this paper: Ahmed, M.J., Afrin, A. and Akhtar, Y. (2019) A Highly Sensitive and Selective Spectrofluorimetric Method for the Determination of Vanadium at Pico-Trace Levels in Some Real, Environmental, Biological, Soil and Food Samples Using 2-( $\alpha$-Pyridyl)-Thioquinaldinamide. American Journal of Analytical Chemistry, $10,528-561$.

https://doi.org/10.4236/ajac.2019.1011038

Received: August 22, 2019

Accepted: November 15, 2019

Published: November 18, 2019

Copyright $\odot 2019$ by author(s) and Scientific Research Publishing Inc. This work is licensed under the Creative Commons Attribution International License (CC BY 4.0).

http://creativecommons.org/licenses/by/4.0/

\section{cc) (i) Open Access}

\begin{abstract}
A new spectrofluorimetric reagent 2-( $\alpha$-pyridyl)-thioquinaldinamide (PTQA) has been synthesized and characterized through novel reaction techniques. A very simple, ultra-sensitive and highly selective non-extractive new spectrofluorimetric method for the determination of vanadium at Pico-trace levels using 2-( $\alpha$-pyridyl)-thioquinaldinamide (PTQA) has been developed. PTQA has been proposed as a new analytical reagent for the direct non-extractive spectrofluorimetric determination of vanadium $(\mathrm{V})$. This novel fluorimetric reagent, PTQA becomes oxidized in a slightly acidic $(0.0035-0.0085 \mathrm{M}$ $\mathrm{H}_{2} \mathrm{SO}_{4}$ ) solution within vanadium (V) in $20 \%$ ethanol to produce highly fluorescent oxidized product $\left(\lambda_{e x}=319 \mathrm{~nm} ; \lambda_{e m}=371 \mathrm{~nm}\right)$. Constant and maximum fluorescence intensities were observed over a wide range of acidity (0.0035 - $0.0085 \mathrm{M} \mathrm{H}_{2} \mathrm{SO}_{4}$ ) for the period between $5 \mathrm{~min}$ and $24 \mathrm{~h}$. Linear calibration graphs were obtained for $0.001-600-\mu \mathrm{g} \cdot \mathrm{L}^{-1}$ of $\mathrm{V}$, having a detection limit of $0.3-\mathrm{ng} \cdot \mathrm{L}^{-1}$; the quantification limit of the reaction system was found to be $3-\mathrm{ng} \cdot \mathrm{L}^{-1}$ and the RSD was $0 \%-2 \%$. A large excess of over 60 cations, anions and complexing agents (like, chloride, phosphate, azide, tartrate, oxalate, $\mathrm{SCN}^{-}$etc.) do not interfere in the determination. The developed method was successfully used in the determination of vanadium in several Certified Reference Materials (alloys, steels, serum, bovine liver, drinking water, soil and sediments) as well as in some environmental waters (potable and pol-
\end{abstract}


luted), biological fluids (human blood, urine, hair and milk), soil samples and food samples (vegetables, rice and wheat) solutions containing both vanadium (IV) and vanadium (V) speciation and complex synthetic mixtures. The results of the proposed method for assessing biological, food and vegetable samples were comparable with inductively coupled plasma optical emission spectroscopy (ICP-OES) and atomic-absorption spectrophotometer (AAS) was found to be in excellent agreement.

\section{Keywords}

Spectrofluorimetry, Vanadium-Determination,

2-( $\alpha$-Pyridyl)-Thioquinaldinamide, Environmental, Biological, Soil, Food-Samples

\section{Introduction}

Vanadium is an essential mineral [1]. Vanadium is used for treating diabetes, low blood sugar, high cholesterol, heart disease, tuberculosis, syphilis, a form of "tired blood" (anemia), and water retention (edema); for improving athletic performance in weight training; and for preventing heart disease and cancer. Over the last several years, a diverse range of bio-logical actions of various vanadium compounds has been documented [1] [2]. Among these, the cardio-protective effects of vanadium have been studied in great detail, and several studies have demonstrated that the vanadyl (IV) form of vanadium possesses cardio-protective properties. Treatment with inorganic and organic compounds of vanadium has been shown to exert a wide range of cardio-protective effects in myocardial ischemia/reperfusion-induced injury, myocardial hypertrophy, hypertension, and vascular disease [1] [2] [3]. Vanadium in trace amounts is important industrially [4], as a: biological nutrient [5], epidemiological preventive [6] and occupational health hazard [7] and it has been said that vanadium can serve as an inhibitor and/or cofactor in various enzyme systems [8] and plays an important role in prevention of heart disease [8]. Human studies suggest that vanadium may lower blood sugar levels and improve insulin sensitivity in patients with type 2 diabetes, according to the University of Maryland Medical Center [9]. Vanadium has become subject of interest among nutritionists since the discovery that various marine species have this metal as an essential element [10] [11]. Foods are the major source of exposure to vanadium for the general population because most of foods contain allow amount of vanadium $(<1 \mathrm{ng} / \mathrm{g})$ [12]. Deficiency problems of vanadium have not been clearly shown in humans, though there is a suspicion that low vanadium can increase susceptibility to heart disease and cancer or lead to higher cholesterol and triglyceride levels [13]. Vanadium is not commonly supplemented or contained in many vitamin-mineral combinations. Some newer formulae may contain small amounts. Eating fish and using vegetable oils in the diet will usually supply sufficient vanadium. On the other hand, it is one of the most important heavy metal pollutants [14]. Its compounds 
can be highly toxic to humans and animals and cause serious diseases [14]. The literature [13] reports that the toxicity of vanadium depends on its oxidation state, $\mathrm{V}(\mathrm{V})$ being more toxic than other species. Therefore, all these facts make it a prime necessity for an accurate determination vanadium at trace levels using simple and rapid methods is of paramount importance.

Many methods have been proposed for the determination of vanadium which include spectrophotometry [15]-[20] and catalytic kinetic methods [21]. Those methods, although sensitive enough, faced several problems with selectivity, especially in food matrixes, where the abundant presence of other metallic ions such as iron, copper, zinc, and molybdenum presented significant interferences. Recently a non-aqueous catalytic method was proposed, after cloud point extraction [22], yielding remarkable results. Electrochemical approaches also produced good results for the determination of vanadium in water samples [23] [24], but in large, the use of element-specific techniques is usually recommended for the analysis of vanadium in food samples [25] [26] [27] [28]. Sophisticated techniques, such as Inductively coupled plasma mass spectrometry (ICP-MS) [29], Inductively coupled plasma atomic emission spectroscopy (ICP-AES) [30] and Inductively coupled plasma optical emission spectroscopy (ICP-OES) [31] [32] as well as flame atomic absorption spectrophotometry (AAS) [33] have been used for the determination of total vanadium. ICP-MS and ICP-OES are highly expensive and are not used for routine analysis in the developing country like Bangladesh. AAS is sensitive but suffer from interferences of matrix condition of samples, such as salinity [34]. However, the spectrofluorimetry is essentially a trace analysis technique and is one of the most powerful tools in chemical analysis. This method still has the advantages of being simple and without requiring expensive or complicated test equipment. For this reason, a wide variety of spectrofluorimetric methods for determination of vanadium has been developed [35]-[60]. Several authors have reported on the extractive spectrofluorimetric determination of vanadium using complexes formed variety of reagents [35]-[60]. In most of the methods [35] [36] [37] [38] cited in literature as shown in Table 1, vanadium forms soluble or insoluble complexes with reagents with various organic solvents for spectrofluorimetric determination of vanadium. Most of these reagents are expensive and non-recoverable. Most of the organic solvents which were used are themselves carcinogenic according to EPA [61]. However, interference from coexist ions, especially for some rare earth ions, $\mathrm{Fe}^{3+}, \mathrm{Mo}^{\mathrm{VI}}$ and $\mathrm{PO}_{4}^{3-}$ are always faced in the existing methods.

The goal of the present work was to develop a simpler direct spectrofluorimetric method for the pico-trace determination of vanadium. In the search for a more sensitive reagent, in this work a new reagent was synthesized according to the method of Porter [62] and a oxidation reaction of 2-( $\alpha$-pyridyl)-thioquinaldinamide (PTQA); with $\mathrm{V}(\mathrm{V})$ and forms an intensely fluorescent oxidized product. Although PTQA has been reported to be spectrofluorimetric reagent for Cr (VI) [63], Se (IV) [64] and Mn (VII) [65] but has not previously been used for the 
Table 1. Comparison of present and existing spectrofluorimetric methods for vanadium.

\begin{tabular}{|c|c|c|c|c|c|c|c|c|c|c|}
\hline 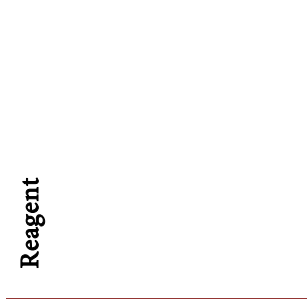 & 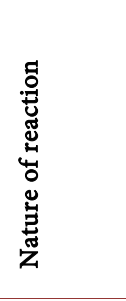 & 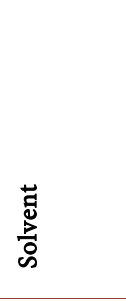 & 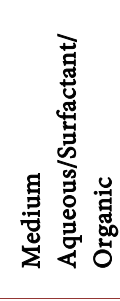 & 垔 & 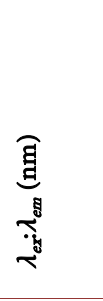 & 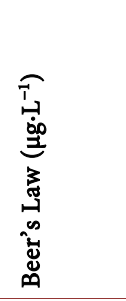 & 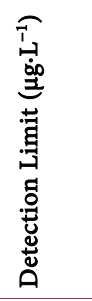 & ঐ̊ & 芯 & 营 \\
\hline o-phenylenediamine $\mathrm{e}^{35}$ & $\begin{array}{l}\text { Catalytic } \\
\text { oxidation }\end{array}$ & Bromate & $\begin{array}{l}\text { Gallic } \\
\text { acid }\end{array}$ & 4.0 & 415:555 & $0-8$ & 6.0 & 5.0 & $\begin{array}{l}\text { Many, } \\
\text { humic acid } \\
\text { and } \mathrm{Fe}^{3+}\end{array}$ & $\begin{array}{l}\text { i) Less selective due to much } \\
\text { interference } \\
\text { ii) Less sensitive } \\
\text { iii) Lengthy and time consuming }\end{array}$ \\
\hline Azomethine- $\mathrm{H}^{36}$ & $\begin{array}{l}\text { Catalytic } \\
\text { oxidation }\end{array}$ & $\begin{array}{l}\text { potassium } \\
\text { bromate }\end{array}$ & Aqueous & 4.2 & $382: 422$ & $\begin{array}{l}5.0 \times 10^{-4} \\
-0.022\end{array}$ & 7.0 & 5 & $\begin{array}{l}\mathrm{Fe}(\mathrm{III}), \\
\mathrm{Ce}(\mathrm{IV})\end{array}$ & $\begin{array}{l}\text { i) Less sensitive } \\
\text { ii) Time consuming } \\
\text { iii) Less selective due to much } \\
\text { interference }\end{array}$ \\
\hline $\begin{array}{l}\text { 1-amino-4-hgdroxyanthra } \\
\text { auinone } \mathrm{e}^{37}\end{array}$ & Oxidation & Ethanol & $\begin{array}{l}\text { Sulfuric } \\
\text { acid }\end{array}$ & 4.2 & $480: 575$ & $100-530$ & 50 & 5 & $\begin{array}{l}\text { Mo (VI), } \\
\text { Fe (III), } \\
\text { Ce (IV) }\end{array}$ & $\begin{array}{l}\text { i) Less selective due to much } \\
\text { interference } \\
\text { ii) Lengthy and time consuming } \\
\text { iii)pH dependent }\end{array}$ \\
\hline rhodamine $6 \mathrm{G}(\mathrm{R} 6 \mathrm{G})^{38}$ & $\begin{array}{l}\text { Catalytic } \\
\text { Oxidation }\end{array}$ & EDTA & $\begin{array}{l}\text { Sulfuric } \\
\text { Acid }\end{array}$ & 2.5 & $525: 555$ & $20-300$ & 2.0 & 4.3 & Many & $\begin{array}{l}\text { i) Less sensitive } \\
\text { ii) Time consuming } \\
\text { iii) Less selective due to much } \\
\text { interference } \\
\text { iv)pH dependent }\end{array}$ \\
\hline $\begin{array}{l}\text { 2-( } \alpha \text {-Pyridyl)-thioquinaldi } \\
\text { namide (Present } \\
\text { Method) }\end{array}$ & $\begin{array}{l}\text { Oxidation } \\
\text { reaction }\end{array}$ & Ethanol & $\begin{array}{l}\text { Acidic } \\
\text { medium }\end{array}$ & $\begin{array}{l}0.05 \\
M\end{array}$ & $319: 371$ & $\begin{array}{l}0.001- \\
600\end{array}$ & $\begin{array}{l}0.3 \\
\mathrm{ng} \cdot \mathrm{L}^{-1}\end{array}$ & & $\begin{array}{l}\text { Nil, using } \\
\text { suitable } \\
\text { masking } \\
\text { agents }\end{array}$ & 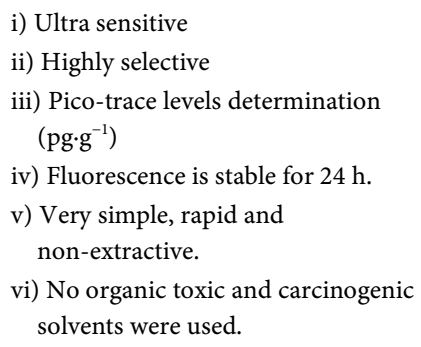 \\
\hline 1,8-diaminonaphthalene $\mathrm{e}^{39}$ & $\begin{array}{l}\text { Catalytic } \\
\text { oxidation }\end{array}$ & $\begin{array}{l}\text { KBr with } \\
\text { Tiron }\end{array}$ & $\begin{array}{l}\text { weakly } \\
\text { acidic } \\
\text { medium }\end{array}$ & $\begin{array}{l}3.6- \\
4.0\end{array}$ & $356: 439$ & $0.05-50$ & 8 & 3 & $\begin{array}{l}\mathrm{Cu}(\mathrm{II}) \text { and } \\
\mathrm{Fe}(\mathrm{III}) \\
\text { interfere } \\
\text { seriously }\end{array}$ & $\begin{array}{l}\text { i) Time consuming \& hence lengthy } \\
\text { ii) Less selective due to much } \\
\text { interference } \\
\text { ii) Less sensitive } \\
\text { iii) } \mathrm{pH} \text { dependent }\end{array}$ \\
\hline
\end{tabular}

spectrofluorimetric determination of vanadium. The method possesses distinct advantages over existing methods [35]-[60] with respect to sensitivity, selectivity, range of determination, simplicity, speed, $\mathrm{pH}$ /acidity range, thermal stability, accuracy, precision and ease of operation. The method is based on the oxidative reaction of non-fluorescent PTQA in a slightly acidic $\left(0.0035-0.0085 \mathrm{M} \mathrm{H}_{2} \mathrm{SO}_{4}\right)$ solution with $\mathrm{V}(\mathrm{V})$ in presence of $20 \%$ ethanol to produce a highly fluorescent oxidized product, followed by a direct measurement of the fluorescence intensity in an aqueous solution at room temperature. Oxidation is very rapid and no extraction is required. With suitable masking, the reaction can be made to be highly selective and the reagent blank solutions do not show any fluorescence. 


\section{Materials and Methods}

\subsection{Apparatus}

A Shimadzu (Kyoto, Japan) (Model-RF-5301PC) Spectrofluorophotometer with 1-cm quartz cells were used and a Jenway (England, UK) (Model-3010) pH meter with combination of electrodes were used for measurements of the fluorescence intensity and $\mathrm{pH}$, respectively. The calibration and linearity of the instrument were frequently checked with standard quinine sulphate $\left(10-\mathrm{mg} \cdot \mathrm{L}^{-1}\right)$. A Shimadzu (Kyoto, Japan) (Model-9800) Inductively Coupled Plasma-Optical Emission Spectrometer (ICP-OES), $\left[\lambda=418 \mathrm{~nm}\right.$, plasma gas flow rate $\left(\mathrm{L} \cdot \mathrm{min}^{-1}\right)=15$, LOD: $1-\mu \mathrm{g} \cdot \mathrm{L}^{-1}$ of V, RF Power $(\mathrm{W})=1400$, Nebulizer gas flow rate $\left(\mathrm{L} \cdot \mathrm{min}^{-1}\right)=1$ 10 and a Shimadzu (Kyoto, Japan) (Model: AA7000) atomic absorption spectrophotometer equipped with a microcomputer-controlled air-acetylene flames were used to compare of the results. The Elemental Analyzer (Exeter Analytical Inc. Model: CE 440) equipped with supersensitive thermal conductivity detector for simultaneous determination of $\mathrm{CHN}$ was used. Infrared spectrum was recorded with a FTIR Spectrophotometer, Shimadzu (Kyoto, Japan) (Model-IR Prestige 21, Detector DTGS KBr) in the range $7500-350 \mathrm{~cm}^{-1}$ and Model: JEOL 500SS, magnetic field strength: $500 \mathrm{MHz}$, solvent used: DMSO D6, standard: TMS, four channel NMR spectrometer with signal-to-noise ratio of 5000:1 for proton were used for characterization of the ligand.

\subsection{Synthesis and Characterization of the Reagent}

\subsubsection{Synthesis of the Reagent}

2- $\left(\alpha\right.$-pyridyl)thioquinaldinamide $\left(\mathrm{PTQA}, \mathrm{C}_{15} \mathrm{H}_{11} \mathrm{~N}_{3} \mathrm{~S}\right)($ Molecular wt. $=265.18)$ was synthesized according to the method of Porter [62]. The mixture containing 2-aminopyridin, quinaldine and sulphur powder in the molar ratio of 2:1:1.5 were mixed and refluxed for 6 hours in 250-mL round bottom flask fitted with bulb condenser under controlled temperature $(140-150)^{\circ} \mathrm{C}$ at $1 \mathrm{~atm}$. pressure over oil bath. The reaction mixture was kept overnight. The thio-compound was filtered and crystallized using petroleum ether $(60-80)^{\circ} \mathrm{C}$ to give a bright yellow crystalline (needle shaped) solid. The compound recrystallized from lime-distilled ethanol and was kept under vacuum $(0.1 \mathrm{~mm}$ of $\mathrm{Hg})$ for 24 hours. Yield of the product was $70 \%$. The structure of the reagent is shown in Figure 1.

\subsubsection{Characterization of the Reagent}

The reagent (PTQA) was characterized by taking the melting point, elemental analysis and an FTIR spectrum (Figure 2) and ${ }^{1}$ HNMR spectrum (Figure 3 ) and thermogravimetric analysis (Figure 4). The melting point of the synthesized compound (PTQA) was $155^{\circ} \mathrm{C} \pm 2^{\circ} \mathrm{C}$ (lit. $155^{\circ} \mathrm{C} \pm 1^{\circ} \mathrm{C}$ ) [65] which indicated the purity of PTQA.

The results elemental analysis $(\mathrm{C}=72.25 \%, \mathrm{~N}=13.35 \%$ and $\mathrm{H}=4.25 \%)$ of the reagent are very in good agreement with the calculated values $(\mathrm{C}=72.43 \%, \mathrm{~N}=$ $13.55 \%$ and $\mathrm{H}=4.55 \%$ ). The FTIR spectrum of prepared reagent (PTQA) is 


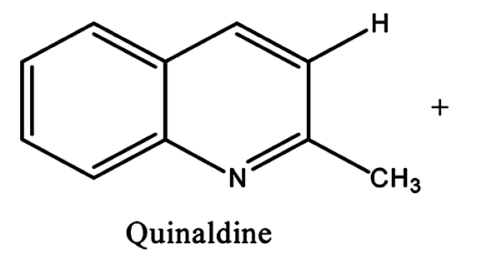

$\mathrm{S}_{8}$<smiles>Nc1ccccn1</smiles>

Sulphur powder

2 - aminopyridine

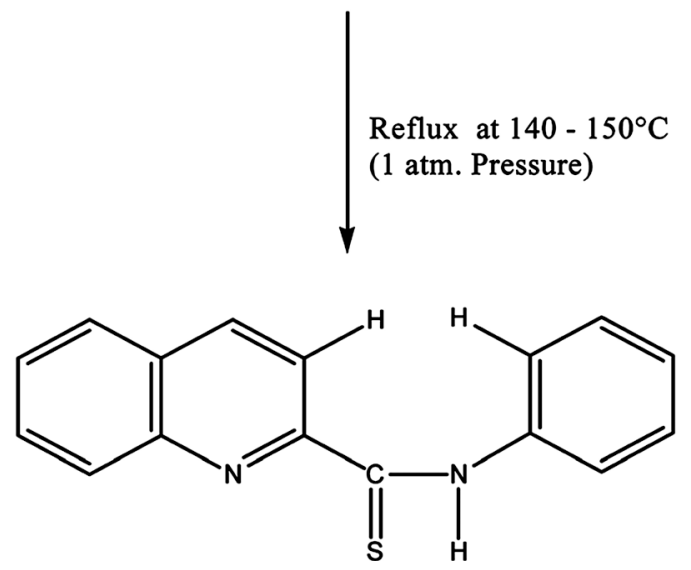

Figure 1. Reaction scheme of 2-( $\alpha$-pyridyl)-thioquinaldinamide (PTQA).

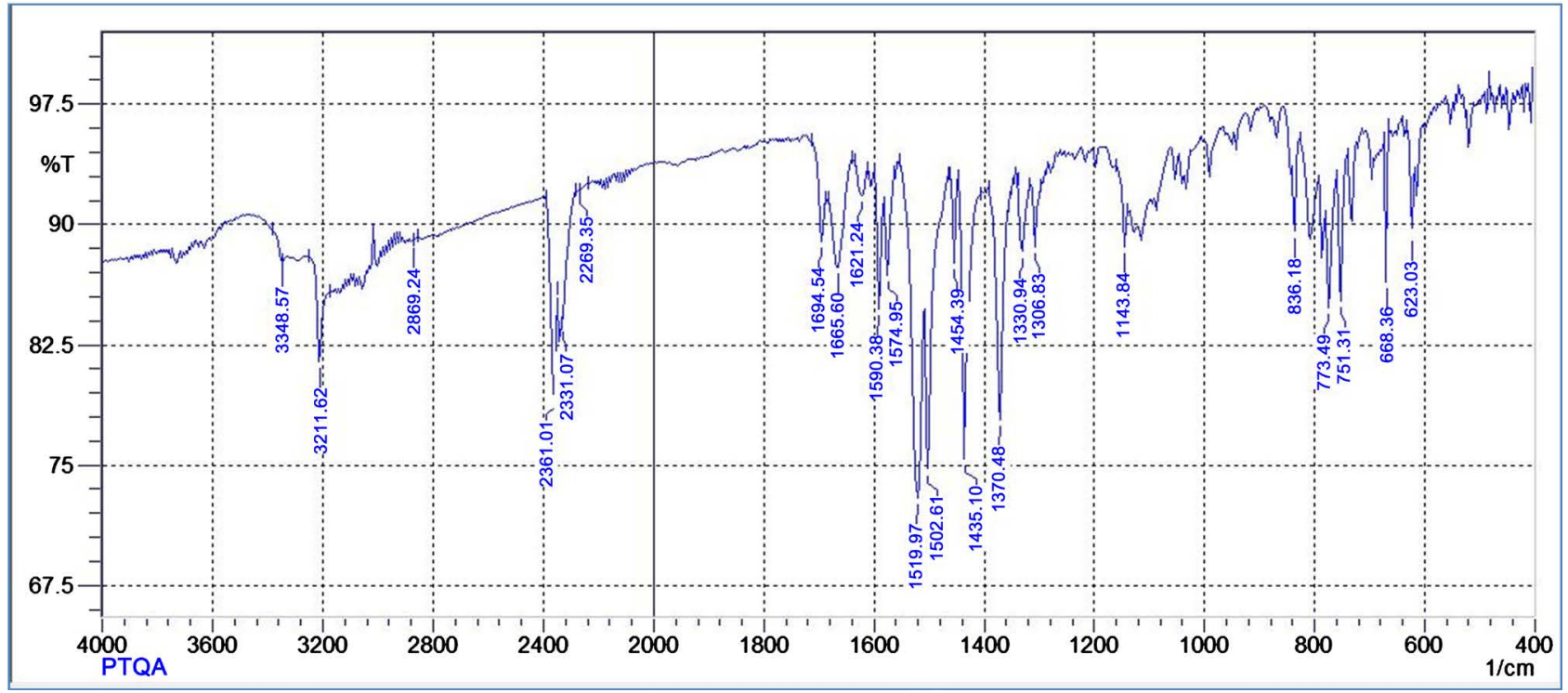

Figure 2. FTIR spectrum of 2-( $\alpha$-pyridyl)-thioquinaldinamide (PTQA).

shown in Figure 2. The presence of FTIR peak at $1126.43 \mathrm{~cm}^{-1}$ in Figure 2 was due to the characteristic $\mathrm{C}=\mathrm{S}$ double bond peak $\left(\nu^{\mathrm{C}=\mathrm{S}}, 1050-1200 \mathrm{~cm}^{-1}\right)$ [65] of the reagent indicating the formation of PTQA. Both FTIR spectral and elemental analysis data indicated the formation of the reagent PTQA. The formation of the reagent also tested by ${ }^{1} \mathrm{HNMR}$ spectrum is shown in Figure 3. The steadiness of the thermogravimetric curve (Figure 4) obtained for about $1 \mathrm{~g}$ of the reagent at $80^{\circ} \mathrm{C}-90^{\circ} \mathrm{C}$ indicated that the reagent did not contain any moisture.

The elemental analysis was performed by the National Center of Excellence in Analytical Chemistry, University of Sindh, Pakistan and FTIR spectra was recorded 


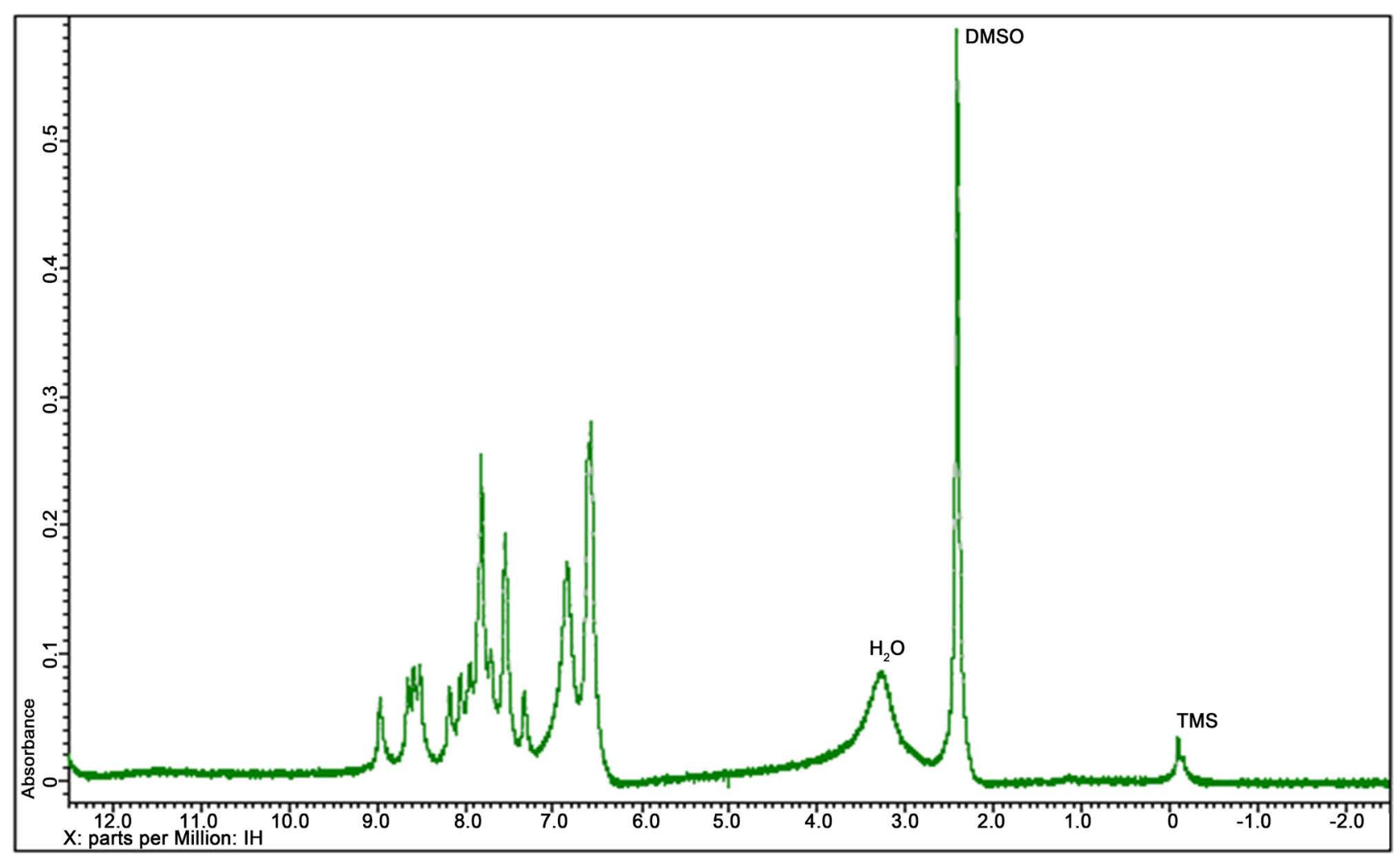

Figure 3. ${ }^{1} \mathrm{HNMR}$ spectrum of 2-( $\alpha$-pyridyl)-thioquinaldinamide (PTQA).

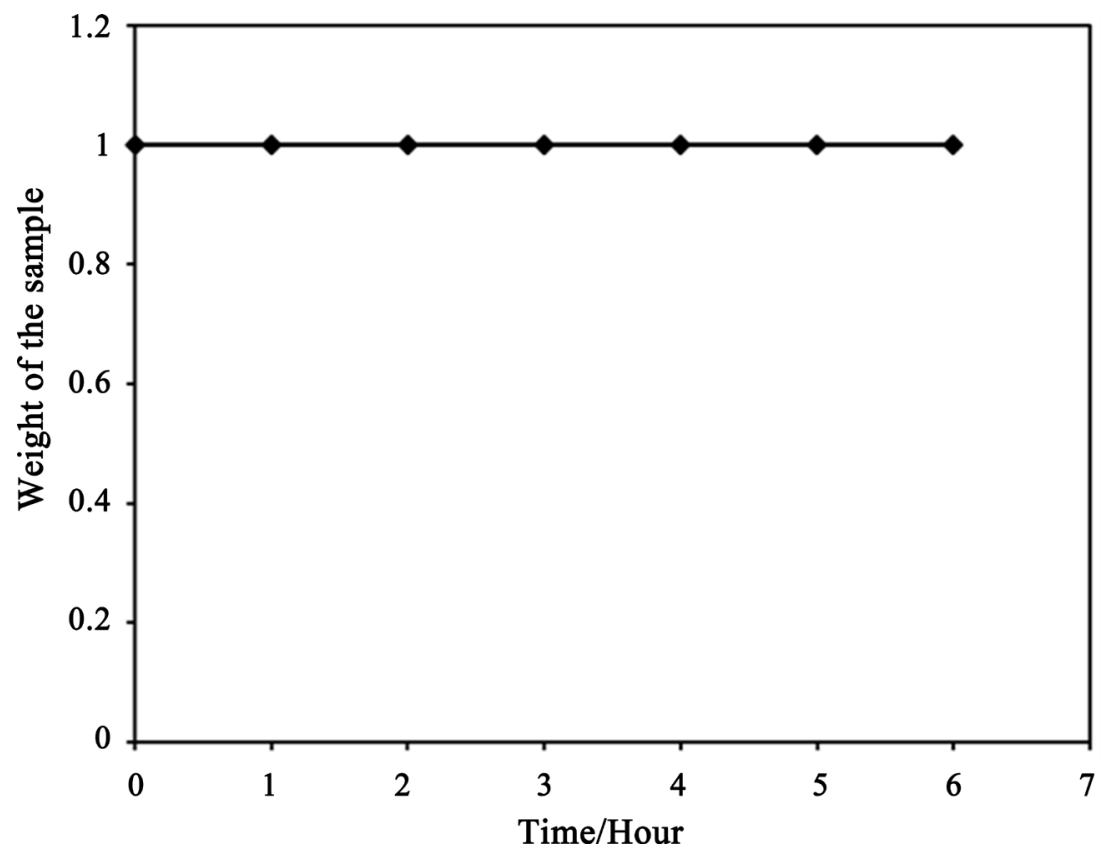

Figure 4. Thermogravimetric curve of 2-( $\alpha$-pyridyl)-thioquinaldinamide at $80^{\circ} \mathrm{C}-90^{\circ} \mathrm{C}$.

with FTIR spectrophotometer Shimadzu (Kyoto, Japan) (Model-IR Prestige 21, Detector DTGS $\mathrm{KBr}$ ) in the range $7500-350 \mathrm{~cm}^{-1}$ from our laboratory and ${ }^{1} \mathrm{HNMR}$ spectrum was recorded ${ }^{1} \mathrm{HNMR}$ spectrophotometer, Model: JEOL 500SS from University of Kanazawa, Japan. 


\section{Reagents and Solutions}

All the chemicals used were of analytical reagent grade of the highest purity available. High-purity absolute ethanol and high-purity de-ionized water was used throughout. High-purity water was obtained by passing tap water through cellulose absorbent and to mixed-bed ion exchange columns, followed by distillation in a corning AG-11 unit. Glass vessel were cleaned by soaking in acidified solutions of $\mathrm{KMnO}_{4}$ or $\mathrm{K}_{2} \mathrm{Cr}_{2} \mathrm{O}_{7}$ followed by washing with concentrated $\mathrm{HNO}_{3}$ and rinsed several times with high purity de-ionized water. Stock solutions and environmental water sample (1000-mL each) were kept in polypropylene bottles containing $1-\mathrm{mL}$ concentrated $\mathrm{HNO}_{3}$. More rigorous contamination control was used when the vanadium levels in the specimens were low.

\subsection{PTQA Solution $\left(3.77 \times 10^{-3} \mathrm{M}\right)$}

The reagent solution was prepared by dissolving the requisite amount $(0.0026 \mathrm{~g})$ of PTQA, in a known volume $(10-\mathrm{mL})$ of absolute ethanol. A freshly prepared reagent solution $\left(3.77 \times 10^{-4} \mathrm{M}\right)$ was used whenever required.

\subsection{Vanadium (V) Standard Solution $\left(1.96 \times 10^{-3} \mathrm{M}\right)$}

A $100-\mathrm{mL}$ amount of stock solution $\left(1-\mathrm{mg} \cdot \mathrm{mL}^{-1}\right)$ of penta valent vanadium was prepared by dissolving $229.6 \mathrm{mg}$ of ammonium metavanadate, $\left(\mathrm{NH}_{4} \mathrm{VO}_{3}\right)$, (Sigma-Aldrich, Merck KGaA, Germany, pro-analysis grade, 99.5\%) in doubly distilled de-ionized water containing 1-2-mL of concentrated nitric acid (1:1). Aliquots of this solution were standardized with EDTA [66]. More dilute standard solutions were prepared by appropriate dilution of aliquots from the stock solution with de-ionized water as and when required. A freshly standardized solution was always used.

\subsection{Vanadium (IV) Standard Solution $\left(1.96 \times 10^{-3} \mathrm{M}\right)$}

A $100-\mathrm{mL}$ amount of stock solution $\left(1-\mathrm{mg} \cdot \mathrm{mL}^{-1}\right)$ of trivalent vanadium was prepared by dissolving 390.7-mg of vanadyl sulfate (Fisher Scientific, pro-analysis grade $99.6 \%$ ) in doubly distilled de-ionized water containing 1-2-mL of concentrated nitric acid (1:1). Aliquots of this solution were standardized with EDTA [66]. More dilute standard solutions were prepared by appropriate dilution of aliquots from the stock solution with de-ionized water as and when required. A freshly standardized solution was always used.

\subsection{Potassium Dichromate Solution}

A $100-\mathrm{mL}$ amount of stock solution $(0.1 \mathrm{~N})$ was prepared by dissolving $500 \mathrm{mg}$ of finely powdered $\mathrm{K}_{2} \mathrm{Cr}_{2} \mathrm{O}_{7}$ (Merck) in 100 - $\mathrm{mL}$ deionized water.

\subsection{Ammonium Persulfate Solution}

Ammonium persulfate solution (2\% w/v) (A.C.S-grade 99\% pure) was freshly prepared by dissolving $2 \mathrm{~g}$ in $100-\mathrm{mL}$ of deionized water. 


\subsection{Tartrate Solution}

A $100-\mathrm{mL}$ stock solution of tartrate $(0.01 \% \mathrm{w} / \mathrm{v})$ was prepared by dissolving $10-\mathrm{mg}$ of A.C.S.-grade ( $99 \%$ pure) potassium sodium tartrate tetrahydrate in (100-mL) de-ionized water.

\subsection{Aqueous Ammonia Solution}

A $100-\mathrm{mL}$ solution of an aqueous ammonia solution was prepared by diluting 10 $\mathrm{mL}$ concentrated $\mathrm{NH}_{4} \mathrm{OH}(28 \%$ - 30\%, A.C.S.-grade) to $100-\mathrm{mL}$ with de-ionized water. The solution was stored in a polypropylene bottle.

\subsection{EDTA Solution}

A $100-\mathrm{mL}$ stock solution of EDTA $(0.01 \% \mathrm{w} / \mathrm{v})$ was prepared by dissolving 10 -mg A.C.S.-grade ( $\geq 99 \%$ pure) ethylene diamine tetra acetic acid as disodium salt dehydrate in $(100-\mathrm{mL})$ de ionized water.

\subsection{Other Solutions}

Solutions of a large number of inorganic ions and complexing agents were prepared from their AnalaR grade or equivalent grade water-soluble salts (or the oxides and carbonates in hydrochloric acid); those of Niobium, Tantalum, Titanium, Zirconium and Hafnium were specially prepared from their corresponding oxides (Specpure, Johnson Matthey) according to the recommended procedures of Mukharjee [67]. In the case of insoluble substances, special dissolution methods were adopted [68].

\section{Procedure}

To 0.1 - 1.0-mL of a neutral aqueous solution containing 0.01 - 6000-ng of vanadium (V) in a 10-mL calibrated flask was mixed with a 1:130 - 1:300-fold molar excess (preferably $1.5-\mathrm{mL})$ of $3.77 \times 10^{-3} \mathrm{M}$ of the 2 -( $\alpha$-pyridyl)-thioquinaldinamide (PTQA) reagent solution followed by the addition of $0.5-2-\mathrm{mL}$ (preferably $1-\mathrm{mL}$ ) of $0.05 \mathrm{M}$ of sulfuric acid. The solution was mixed well and allowed to stand for 5 min after which $2-\mathrm{mL}$ of absolute ethanol was added and the mixture was diluted to the mark with de-ionized water. The fluorescence intensity of the system was measured at 371-nm against a corresponding reagent blank, prepared concurrently, keeping the excitation wavelength maximum at $319-\mathrm{nm}$ and the instrument setting the same. The vanadium content in an unknown sample was determined using a concurrently prepared calibration graph.

\section{Sample Collection and Preservation [69]}

\subsection{Environmental Samples}

Water and soil samples were collected in polythene bottles from different places of Bangladesh. After collection, $\mathrm{HNO}_{3}\left(1-\mathrm{mL} \cdot \mathrm{L}^{-1}\right)$ was added as preservative. 


\subsection{Blood, Urine and Milk}

Blood and urine samples were collected in polythene bottles from effected persons of Chittagong Medical College Hospital, Bangladesh. Milk sample was collected from a Bangladeshi lactating mother. Immediately after collection they were stored in a salt-ice mixture and latter, at the laboratory, were at $-20^{\circ} \mathrm{C}$.

\subsection{Soil Samples}

Soil samples were collected from different locations of Bangladesh. Samples were dried in air and homogenized with a mortar.

\subsection{Food Samples}

Food samples (rice, wheat, fruits and vegetables) were collected from local market of Chittagong. After collection the samples (fruits and vegetables) were stored in refrigerator for preservation. Samples (rice, wheat) were used as dry condition and homogenized with a mortar.

\section{Results and Discussion}

\subsection{Factors Affecting the Fluorescence Intensity}

\section{Excitation and emission spectra}

Vanadium (V) fluoresces strongly in PTQA solution when irradiated with ultraviolet light. The excitation and emission spectra of the fluorescent V(V)-PTQA in $0.005 \mathrm{M}$ sulfuric acid medium was recorded using the spectrofluorophotometer. The excitation and emission maxima were at $319 \mathrm{~nm}$ and $371 \mathrm{~nm}$, respectively. The reagent blank exhibited negligible fluorescence, despite having wavelength maximum in the same region. In all instances, measurements were made against the reagent blank. The spectra are shown in Figure 5.

\subsection{Optimization of Some Parameters on the Fluorescence Intensity}

\subsubsection{Effect of Solvent}

Because PTQA is insoluble in water, an organic solvent was used for the system. Of the various solvents [chloroform, benzene, carbon tetrachloride, n-butanol, isobutanol, ethanol, 1, 4-dioxane and N,N-dimethylformamide (DMF)] were tested for the system, ethanol was found to be the best solvent for the system. The effect of ethanol on the fluorescence intensity was studied and no adverse effect was observed over a wide range $(20 \%-70 \%)$ of ethanol concentrations. It was observed that $\mathrm{V}^{\mathrm{V}}$-PTQA system with $10-\mu \mathrm{g} \cdot \mathrm{L}^{-1}$ of $\mathrm{V}^{\mathrm{V}}$ in absolute ethanol solution produced constant fluorescence intensity as shown in Figure 6. A concentration of $20 \% \mathrm{v} / \mathrm{v}$ ethanol in the final volume was sufficient to prevent any precipitation or turbidity and to allow accurate measurements. Therefore, a 20\% $\mathrm{v} / \mathrm{v}$ ethanolic solution was used in the recommended procedure.

\subsubsection{Effect of Acidity}

The oxidation reaction was conducted in acid medium to avoid the formation of 


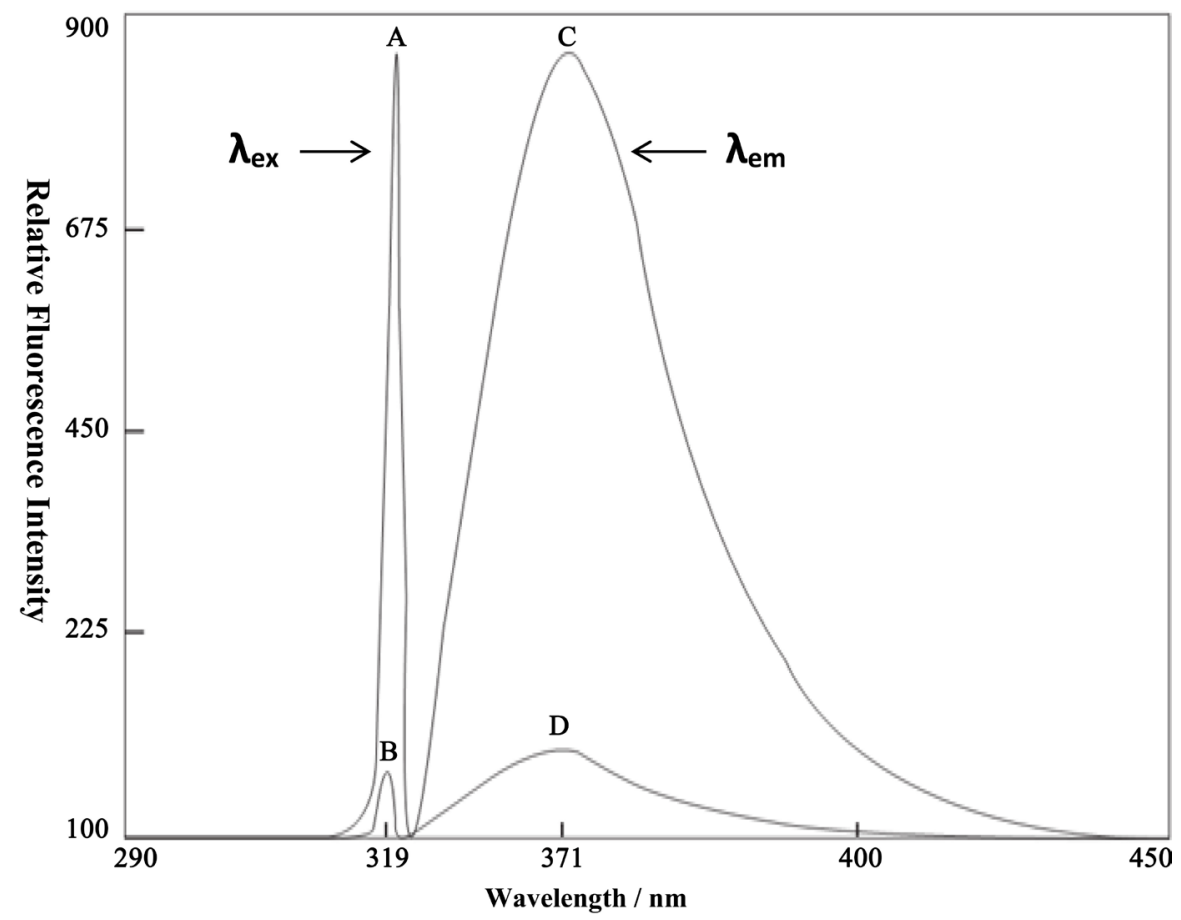

Figure 5. Spectra A \& B are the excitation spectra of $\mathrm{V}^{\mathrm{V}}$-PTQA system and reagent blank $\left(\lambda_{e x}=319 \mathrm{~nm}\right)$, respectively; $C$ and $\mathrm{D}$ are the corresponding emission spectra $\left(\lambda_{e m}=371\right.$ $\mathrm{nm})$ in aqueous solutions.

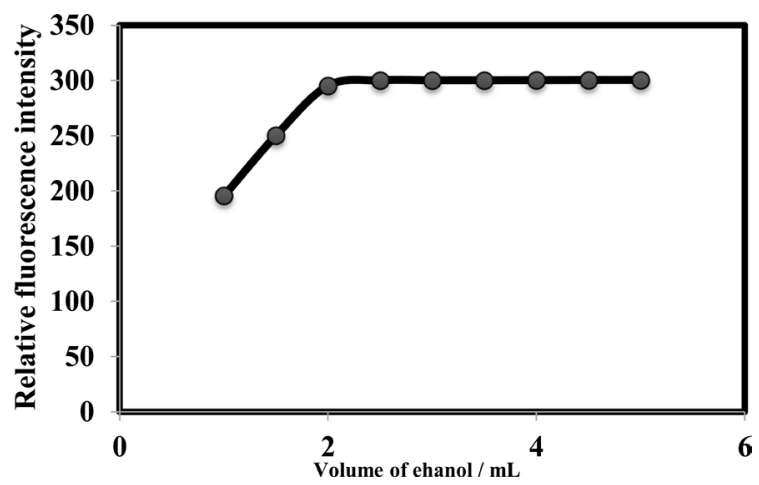

Figure 6. Effect of solvent (Ethanol) on the fluorescence of $\mathrm{V}^{\mathrm{V}}$-PTQA system.

precipitation of vanadium. In order to determine the most suitable acid for the reaction, different acids (nitric, sulfuric, hydrochloric and phosphoric) were studied. But, sulfuric acid was found to be the best acid than any other mineral acids for the system. The fluorescence intensity was at maximum and constant when the 10-mL of solution (10- $\mu \mathrm{g} \cdot \mathrm{L}^{-1}$ of $\left.\mathrm{V}^{\mathrm{V}}\right)$ contained $0.5-2$ - $\mathrm{mL}$ of $0.05 \mathrm{M}$ sulfuric acid at room temperature $(25 \pm 5)^{\circ} \mathrm{C}$. Outside this range of acidity, the fluorescence intensity decreased (Figure 7). The optimum acidity range in the final solution is therefore $0.0035-0.0085 \mathrm{M}$ (preferably $0.005 \mathrm{M}$ ) $\mathrm{H}_{2} \mathrm{SO}_{4}$. Therefore, 1-mL of 0.05 $\mathrm{M}$ sulfuric acid solution was used for all subsequent measurements.

\subsubsection{Effect of Temperature}

The influence of temperature was studied between $10^{\circ} \mathrm{C}-80^{\circ} \mathrm{C}$. It could be 


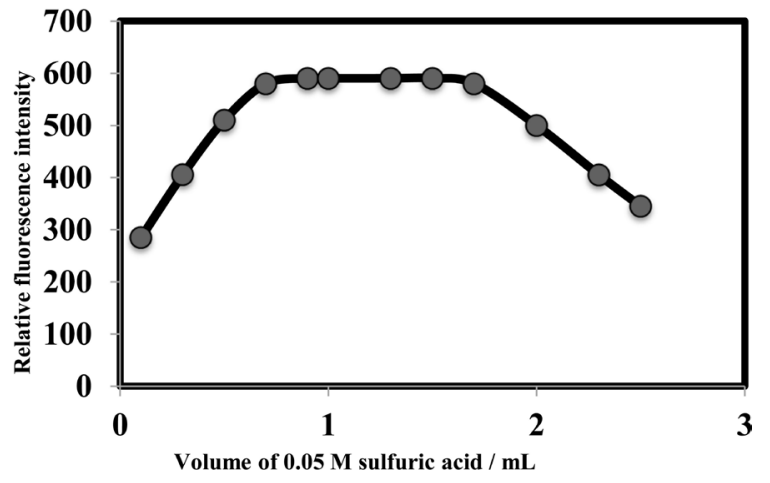

Figure 7. Effect of acidity on the fluorescence of $\mathrm{V}^{\mathrm{V}}$-PTQA system.

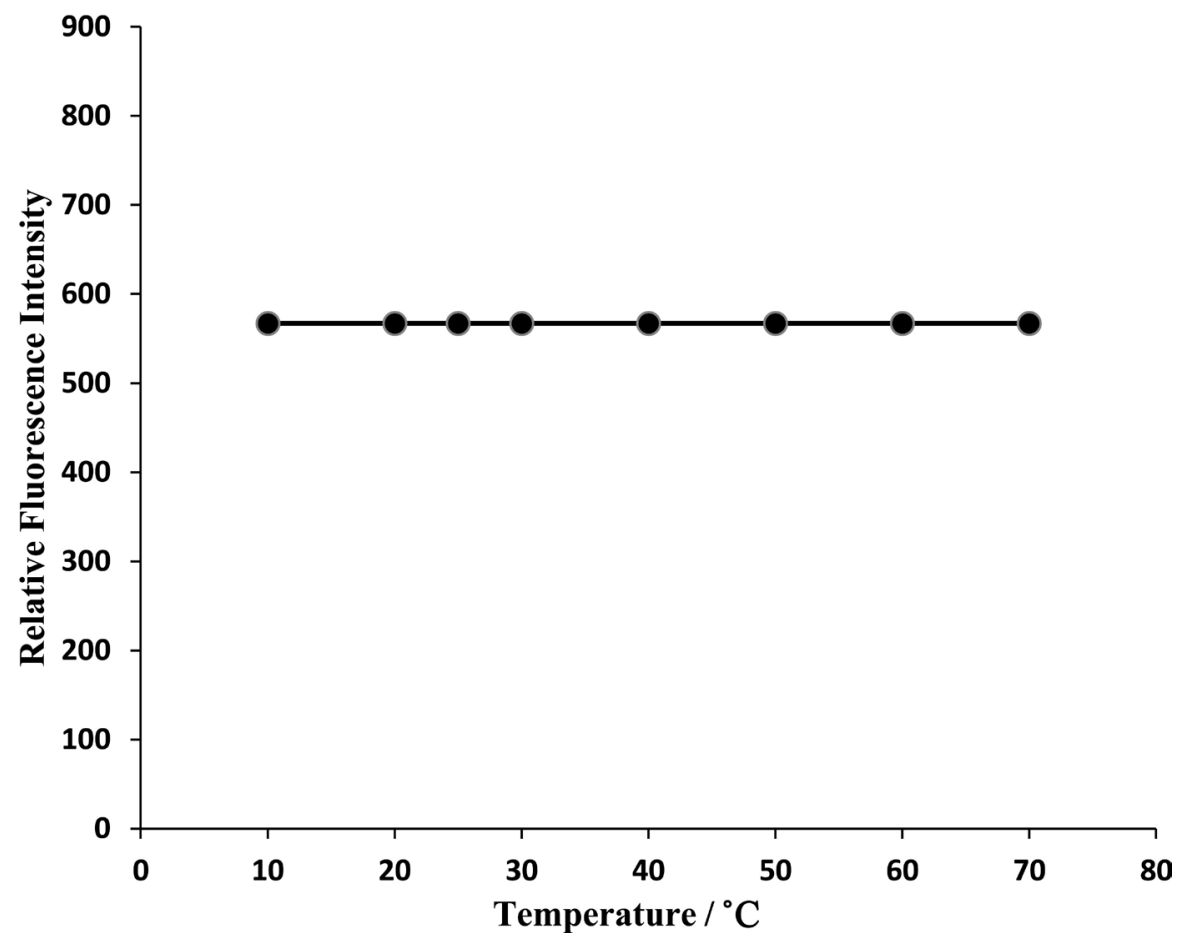

Figure 8. Effect of temperature on the fluorescence of $\mathrm{V}^{\mathrm{V}}$-PTQA system.

observed from Figure 8 that temperature effects not pronounced between $10^{\circ} \mathrm{C}$ $80^{\circ} \mathrm{C}$ and so room temperature $(25 \pm 5)^{\circ} \mathrm{C}$ is recommended for all subsequent measurements.

\subsubsection{Effect of Time}

The reaction is instantaneous. The $\mathrm{V}^{\mathrm{V}}$-PTQA system attained maximum and constant fluorescence intensity immediately (within $5 \mathrm{~min}$ ) after dilution of the solution to the final volume, which then remained strictly unaltered for $24 \mathrm{~h}$ at room temperature $\left(25^{\circ} \mathrm{C} \pm 5^{\circ} \mathrm{C}\right)$ shown in Figure 9.

\subsubsection{Effect of Reagent Concentration}

The intensities of the fluorescence of a series of solutions containing a constant amount of $\mathrm{V}(\mathrm{V})$ with varying amounts of PTQA were measured in order to establish the optimum concentration of PTQA. The change of fluorescence inten- 
sity with PTQA concentration was shown in Figure 10, while the concentration of $\mathrm{V}^{\mathrm{V}}$ was kept constant. It was found that the fluorescence intensity increase at first as the PTQA concentration rises and reaches a maximum, but further addition of PTQA hardly effect the intensity even PTQA is more times concentrated than $\mathrm{V}^{\mathrm{V}}$. It was observed that at $10-\mu \mathrm{g} \cdot \mathrm{L}^{-1} \mathrm{~V}^{\mathrm{V}}$ metal and the reagent molar ratios of 1:130 - 1:300 produced a constant fluorescence intensity of the oxidized product. Outside this range of reagent, the fluorescence intensity get decreased (Figure 9). At different $\mathrm{V}^{\mathrm{V}}$ concentrations $\left(0.5\right.$ and $\left.1-\mu \mathrm{g} \cdot \mathrm{L}^{-1}\right)$, the effect of varying the reagent concentration was similar. For all subsequent measurements $1.5-\mathrm{mL}$ of $3.77 \times 10^{-3}$ MPTQA reagent was added.

\subsubsection{Calibration Curves (Beer's Law)}

The calibration graphs for the determination of $\mathrm{V}(\mathrm{V})$ were constructed under optimum conditions. The well-known equation for spectrofluorimetric analysis in very dilute solutions derived from Beer's law. The effect of metal concentration was studied over $0.001-1000-\mu \mathrm{g} \cdot \mathrm{L}^{-1}$ distributed in six different sets $(0.001$ $0.01,0.01-0.1,0.1-1,1-10,10-100$ and $\left.100-1000-\mu \mathrm{g} \cdot \mathrm{L}^{-1}\right)$ for convenience of

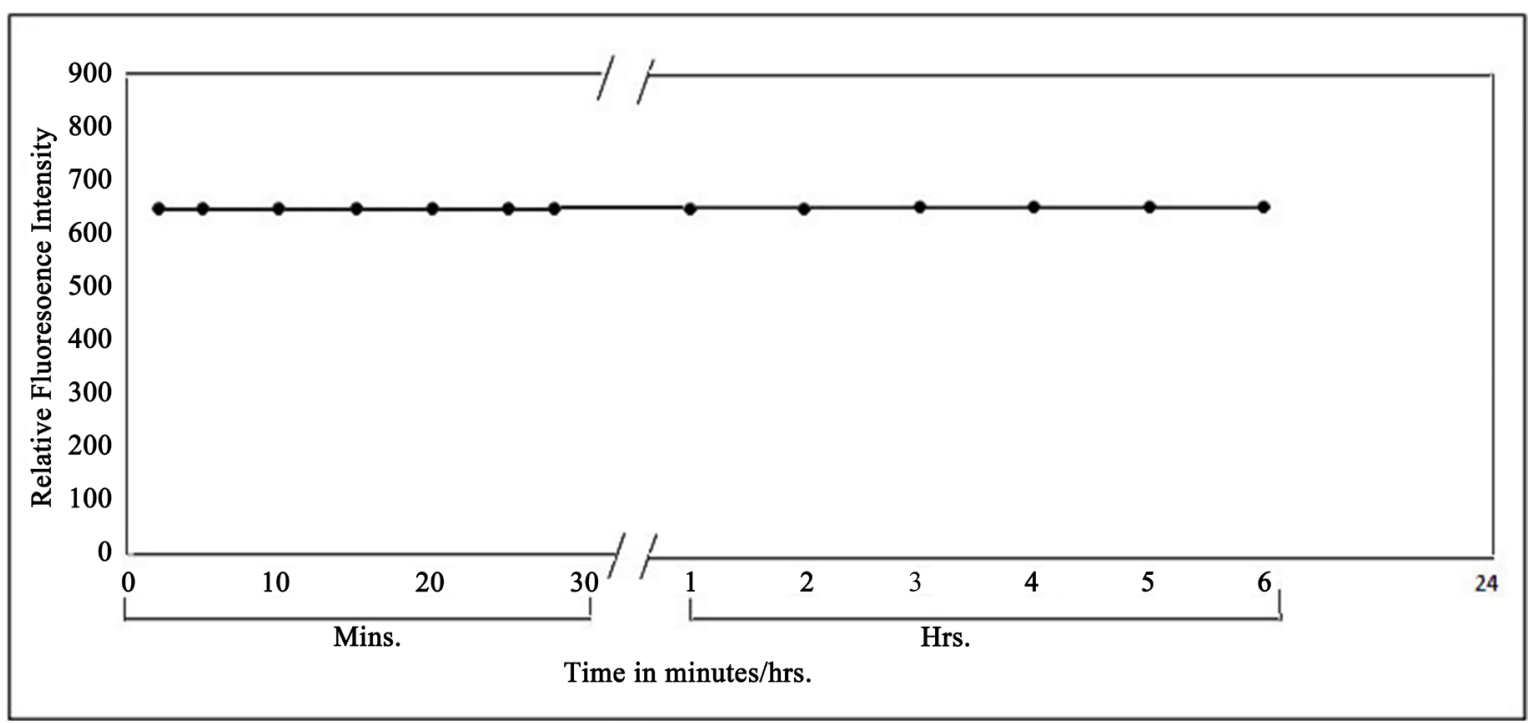

Figure 9. Effect of the time on the fluorescence of $\mathrm{V}^{\mathrm{V}}$-PTQA system.

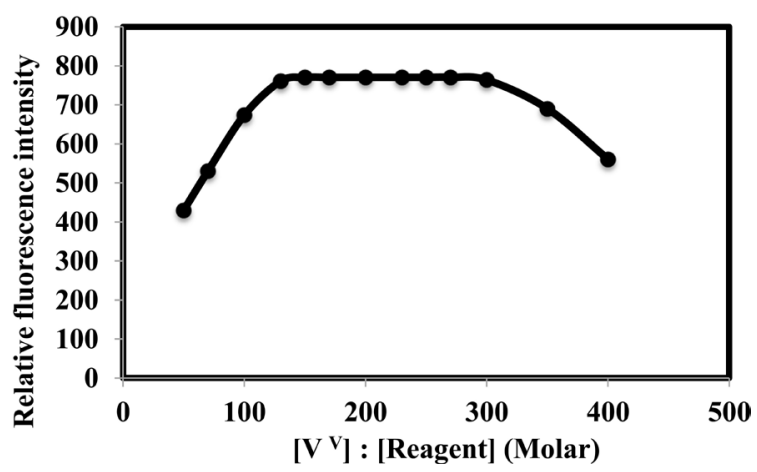

Figure 10. Effect of reagent (PTQA: $\mathrm{V}^{\mathrm{V}}$ molar concentration) on the fluorescence of $\mathrm{V}^{\mathrm{V}}$-PTQA system. 
measurement. The fluorescence intensity was linear over a wide range $1 \mathrm{pg} \cdot \mathrm{mL}^{-1}$ to $600-\mu \mathrm{g} \cdot \mathrm{mL}^{-1}$ for $0.001-600-\mu \mathrm{g} \cdot \mathrm{L}^{-1}$ of vanadium $(\mathrm{V})$ at excitation wavelength at $319 \mathrm{~nm}$ and emission wavelength at $371 \mathrm{~nm}$, representing six linear graphs (0.001 - 0.01, $\left.01-0.1,0.1-1.0,1.0-10,10-100,100-1000-\mu \mathrm{g} \cdot \mathrm{L}^{-1}\right)$ as shown in Figures 11-16, respectively. Of six calibration graphs, the one showing the limit of the linearity range (Figure 16); the remaining five (Figures 11-15) were straight-line graphs passing through the origin $\left(\mathrm{R}^{2}=0.9998\right)$. The limit of detection

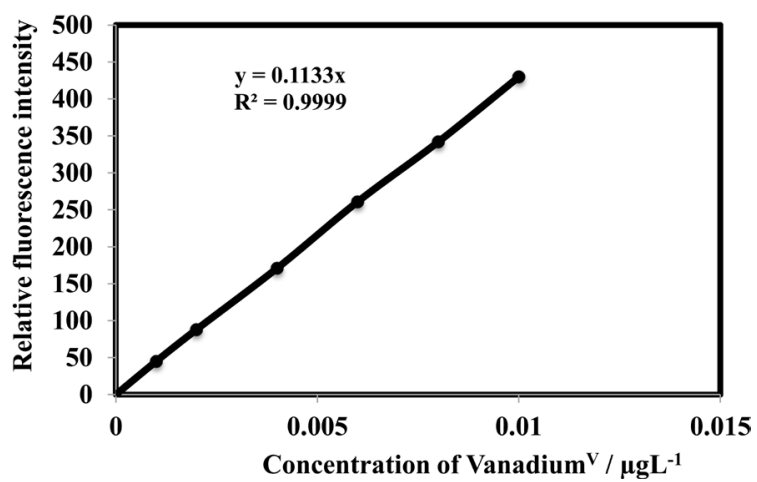

Figure 11. Calibration graph A: $0.001-0.01-\mu \mathrm{g} \cdot \mathrm{L}^{-1}$ of vanadium (V). Bandwidth: Ex.slit-3, Em.slit-3. Sensitivity: High.

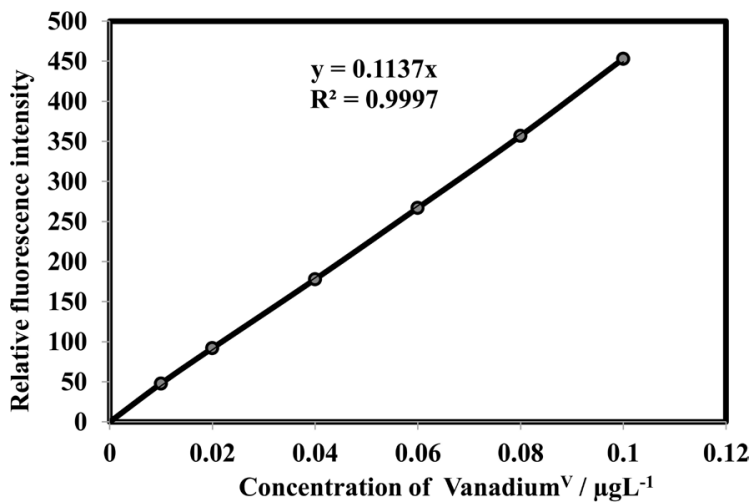

Figure 12. Calibration graph B: $0.01-0.1 \mu \mathrm{g} \cdot \mathrm{L}^{-1}$ of vanadium (V). Bandwidth: Ex.slit-1.5, Em.slit-3. Sensitivity: High.

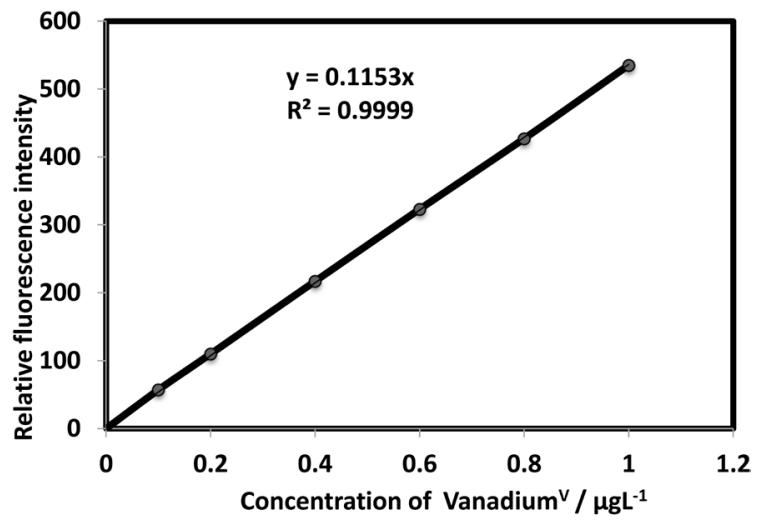

Figure 13. Calibration graph C: $0.1-1-\mu \mathrm{g} \cdot \mathrm{L}^{-1}$ of vanadium (V). Bandwidth: Ex.slit-5, Em.slit-1.5. Sensitivity: High. 


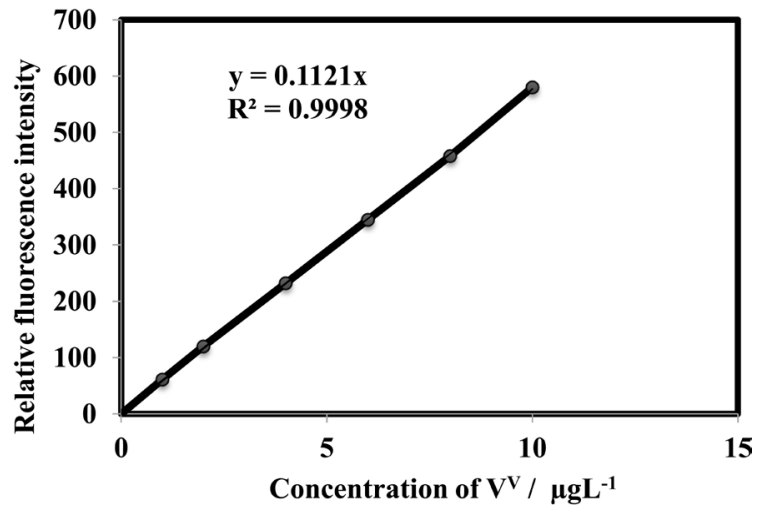

Figure 14. Calibration graph D: $1-10-\mu \mathrm{g} \cdot \mathrm{L}^{-1}$ of vanadium (V). Bandwidth: Ex.slit-3, Em.slit-1.5. Sensitivity: High.

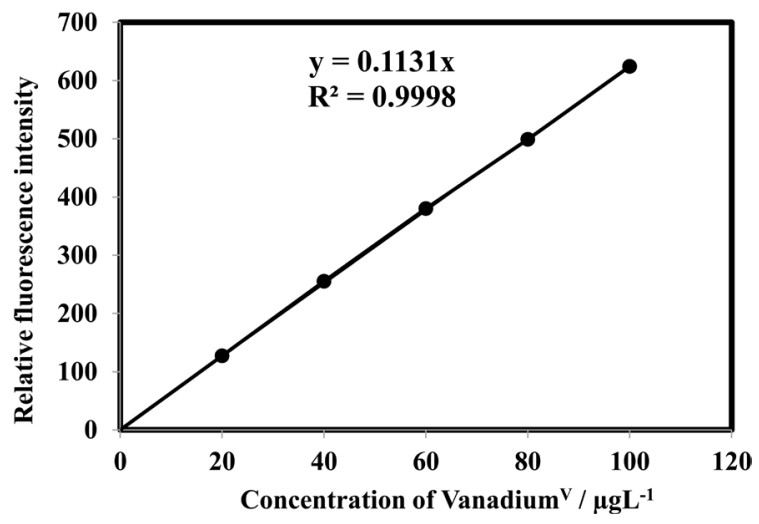

Figure 15. Calibration graph E: $10-100-\mu \mathrm{g} \cdot \mathrm{L}^{-1}$ of vanadium (V). Bandwidth: Ex.slit-5, Em.slit-1.5. Sensitivity: High.

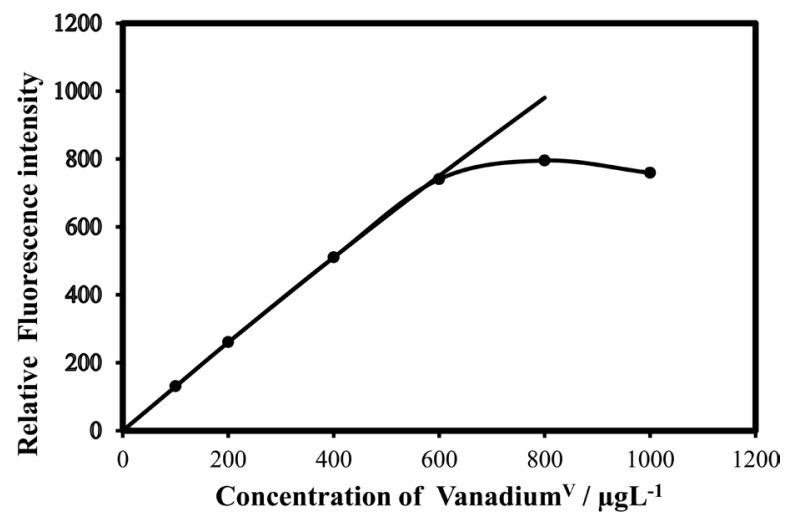

Figure 16. Calibration graph F: $100-600-\mu \mathrm{g} \cdot \mathrm{L}^{-1}$ of vanadium (V). Bandwidth: Ex.slit-1.5, Em.slit-1.5. Sensitivity: High.

and limit of quantization were found to be $0.3-\mathrm{ng} \cdot \mathrm{L}^{-1}$ and $3-\mathrm{ng} \cdot \mathrm{L}^{-1}$, respectively. The selected analytical parameters obtained with the optimization experiments are summarized in Table 2 .

\subsection{Effect of Foreign Ions}

In order to apply the proposed method to the determination of the concentra- 
tion of $\mathrm{V}(\mathrm{V})$ in the real sample, the effect of some co-existing species was investigated using $10-\mu \mathrm{g} \cdot \mathrm{L}^{-1}$ of vanadium $(\mathrm{V})$. More than 60 anions, cations and complexing agents were studied individually to investigate their effect on the determination of $10-\mu \mathrm{g} \cdot \mathrm{L}^{-1}$ of vanadium $(\mathrm{V})$. The criterion for interference [70] was a fluorescence intensity value varying by more than $\pm 5 \%$ from the expected value for vanadium alone. The results are summarized in Table 2. As can be seen a large number of ions have no significant effect on the determination of vanadium. The most serious interference was from Se (IV), $\mathrm{Cr}$ (VI) and Mn (VII).

Most of the ions were tolerated over 1000 exceeds. Ascorbic acid, oxalate, citrate, tartrate, EDTA and fluoride ions etc. were tolerated over 5000 folds. In order to eliminate the interference of Se (IV), Cr (VI) and Mn (VII) ions, EDTA and tartrate can be used as masking agents, respectively [71]. A 100-fold excess of Se (IV), Cr (VI) and Mn (VII) ions could be masked with EDTA and tartrate respectively. During the interference studies, if a precipitated was formed, it was removed by centrifugation. Strong reducing agents such as, tin (II), chloride, iron (II), sulfate, hydroxylamine, hydrochloride and sodium azide, which would otherwise reduce vanadium $(\mathrm{V})$, undergo oxidation during the treatment of the vanadium (IV) solution with persulphate and hence are not a problem [72]. The amount mentioned is not the tolerance limit but the actual amount studied. However, for those ions whose tolerance limits have been studied, their tolerance ratios are mentioned in Table 3.

Table 2. Selected analytical parameters obtained with the optimization experiments.

\begin{tabular}{|c|c|c|}
\hline Parameters & Studied range & Selected value \\
\hline Excitation wavelength maximum $/ \lambda_{e x}(\mathrm{~nm})$ & $200-700$ & 319 \\
\hline Emission wavelength maximum $/ \lambda_{e m}(\mathrm{~nm})$ & $200-700$ & 371 \\
\hline Solvent/amount of ethanol/mL & $0-5$ & $\begin{array}{c}2-5 \\
\text { (Preferably 2) }\end{array}$ \\
\hline Acidity $/ \mathrm{M} \mathrm{H}_{2} \mathrm{SO}_{4} / \mathrm{mL}$ & $0.0005-0.02$ & $\begin{array}{c}0.0035-0.0085 \\
\text { (Preferably 0.005) }\end{array}$ \\
\hline $\mathrm{pH}$ & $3.30-1.70$ & $\begin{array}{c}2.35-2.07 \\
\text { (Preferably } 2.30 \text { ) }\end{array}$ \\
\hline Time/h & $0-72$ & $\begin{array}{c}1 \mathrm{~min}-24 \mathrm{~h} \\
\text { (Preferably } 5 \text { ) }\end{array}$ \\
\hline Temperature $/{ }^{\circ} \mathrm{C}$ & $10-70$ & $\begin{array}{c}15-50 \\
\text { (Preferably } 25 \pm 5)\end{array}$ \\
\hline $\begin{array}{c}\text { Reagent } \\
\text { (fold molar excess, M:R) }\end{array}$ & $1: 50-1: 400$ & $\begin{array}{c}1: 130-1: 300 \\
\text { (Preferably 1:150) }\end{array}$ \\
\hline Linear range $/ \mu \mathrm{g} \cdot \mathrm{L}^{-1}$ & $0.0001-1000$ & $0.001-600$ \\
\hline Limit of quantization/ng. $\mathrm{L}^{-1}$ & $0.1-100$ & 3.0 \\
\hline Detection limit/ng. $\mathrm{L}^{-1}$ & $0.01-10.0$ & 0.3 \\
\hline Reproducibility (\% RSD) & $0-10$ & $0-2 \%$ \\
\hline Regression Coefficient $\left(\mathrm{R}^{2}\right)$ & $0.9995-0.9999$ & 0.9998 \\
\hline
\end{tabular}


Table 3. Table of tolerance limits of foreign ions ${ }^{\mathrm{a}}$, tolerance ratio [species $\left.(\mathrm{x}) / \mathrm{V}^{\mathrm{V}}(\mathrm{w} / \mathrm{w})\right]$.

\begin{tabular}{|c|c|c|c|}
\hline Species $\mathbf{x}$ & $\begin{array}{l}\text { Tolerance Ratio } \\
\mathrm{x} / \mathrm{V}(\mathrm{w} / \mathrm{w})\end{array}$ & Species $\mathbf{x}$ & $\begin{array}{c}\text { Tolerance Ratio } \\
\mathrm{x} / \mathrm{V}(\mathrm{w} / \mathrm{w})\end{array}$ \\
\hline Ammonium & 1000 & Iron (III) & $500^{\mathrm{b}}$ \\
\hline Aluminium & 1000 & Lead (II) & 1000 \\
\hline Azide & 1000 & Magnesium & 1000 \\
\hline Arsenic (III) & 1000 & Manganese (II) & 1000 \\
\hline Arsenic (V) & $100^{\mathrm{b}}$ & Manganese (VII) & $300^{c}$ \\
\hline Ascorbic acid & 1000 & Mercury (II) & 1000 \\
\hline Antimony & 1000 & Molybdenum (VI) & $500^{\mathrm{b}}$ \\
\hline Barium & 1000 & Nitrate & 1000 \\
\hline Bromide & 1000 & Nickel & 1000 \\
\hline Bismuth (III) & 1000 & Oxalate & 1000 \\
\hline Beryllium (II) & 1000 & Potassium & 1000 \\
\hline Calcium & 1000 & Selenium (IV) & $100^{c}$ \\
\hline Chloride & 1000 & Selenium (VI) & 1000 \\
\hline Cobalt (II) & 1000 & Silver & 1000 \\
\hline Cobalt (III) & 1000 & Sodium & 1000 \\
\hline Copper (II) & 1000 & Strontium & 1000 \\
\hline Chromium (III) & 1000 & Sulfate & 1000 \\
\hline Chromium (IV) & $100^{c}$ & Tellurium (IV) & 1000 \\
\hline Cadmium & 1000 & Tellurium (VI) & 1000 \\
\hline Carbonate & 1000 & Titanium (IV) & 1000 \\
\hline Cesium & 1000 & Tartrate & 1000 \\
\hline Citrate & 1000 & Thiocyanate & 1000 \\
\hline Cerium (III) & 1000 & Thiourea & 1000 \\
\hline Cerium (IV) & $100^{\mathrm{b}}$ & Tungsten (VI) & 1000 \\
\hline Cyanide & 1000 & Tin (II) & 1000 \\
\hline EDTA & 1000 & Tin (IV) & 1000 \\
\hline Fluoride & 1000 & Uranium (VI) & 1000 \\
\hline Iodide & 1000 & Thallium (III) & $100^{c}$ \\
\hline Iron (II) & 1000 & Zinc & 1000 \\
\hline
\end{tabular}

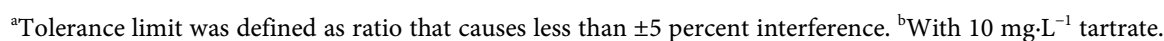
'With $10 \mathrm{mg} \cdot \mathrm{L}^{-1}$ EDTA.

\subsection{Precision and Accuracy}

The precisions of the present method were proved by measuring 10 solutions of same sample (each analyzed at least five times). The relative standard deviation $(\mathrm{n}=5)$ was $0 \%-2 \%$ for $0.01-6000-\mathrm{ng}$ of vanadium $(\mathrm{V})$ in $10-\mathrm{mL}$, indicating that this method is highly precise and reproducible (Table 2). The detection limit (3 s 
of the blank) and limit of quantization (10 times of detection limit) for vanadium (V) were found to be $0.3-\mathrm{ng} \cdot \mathrm{L}^{-1}$ and $3-\mathrm{ng} \cdot \mathrm{L}^{-1}$, respectively. The method was also tested by analyzing several synthetic mixtures containing vanadium $(\mathrm{V})$ and diverse ions (Table 4). The results for total vanadium were in excellent agreement with certified values (Table 5). The reliability of the procedure was tested by recovery studies. The average percentage recovery obtained for addition of vanadium $(\mathrm{V})$ spike to some environmental water samples was quantitative, as shown in Table 6 . The results of biological analyses by the spectrofluorimetric method were in excellent agreement with those obtained by ICP-OES (Table 7). The results of soil analyses by the spectrofluorimetric method were excellent agreement with those obtained by AAS (Table 8). The results of food and vegetables analyses by spectrofluorimetric method were also found to be in excellent agreement with those obtained by ICP-OES (Table 9). The results of speciation of vanadium (IV) and vanadium (V) in mixtures were highly reproducible (Table 10). Hence, the precision and accuracy of the method were found to be excellent.

\subsection{Nature of the Fluorescent Species}

The non fluorescent reagent, PTQA, produced the same spectral characteristics with excitation and emission wavelengths almost invariably around $319 \mathrm{~nm}$ and $371 \mathrm{~nm}$, with vanadium (V), manganese (VII), chromium (VI), selenium (IV) and with persulphate, hydrogen peroxide, and triiodide in acidic media. This indicates that the fluorescence species is an oxidized product of the reagent itself and not a chelate. Similar oxidative fluorescent reactions have been utilized previously [65] [72]. The PTQA reagent produced here has so many potential reaction sites that the structure of the oxidized fluorescent species is difficult to

Table 4. Determination of vanadium in some synthetic mixtures.

\begin{tabular}{|c|c|c|c|c|}
\hline \multirow[b]{2}{*}{ Sample } & \multirow{2}{*}{$\begin{array}{l}\text { Composition of Mixtures } \\
\left(\mu \mathrm{g} \cdot \mathrm{L}^{-1}\right)\end{array}$} & \multicolumn{3}{|c|}{ Vanadium $/ \mu \mathrm{g} \cdot \mathrm{L}^{-1}$} \\
\hline & & Added & $\begin{array}{l}\text { Found }^{a} \\
(n=5)\end{array}$ & $\begin{array}{c}\text { Recovery } \pm S^{b} \\
(\%)\end{array}$ \\
\hline \multirow{2}{*}{ A } & \multirow{2}{*}{$\mathrm{V}(\mathrm{V})$} & 1.0 & 0.99 & $99 \pm 0.5$ \\
\hline & & 50 & 50.0 & $100 \pm 0.0$ \\
\hline \multirow{2}{*}{ B } & As in $\mathrm{A}+\mathrm{Cr}^{\mathrm{VI}}(50)+\mathrm{As}^{\mathrm{V}}(50)+\mathrm{Ti}^{\mathrm{IV}}(50)$ & 1.0 & 1.0 & $100 \pm 0.0$ \\
\hline & $+\mathrm{Fe}^{3+}(50)+\operatorname{EDTA}(50)$ & 50 & 49.5 & $99 \pm 0.6$ \\
\hline \multirow{2}{*}{ C } & As in $\mathrm{B}+\mathrm{Pb}^{2+}(50)+\mathrm{Bi}^{3+}(50)+\mathrm{Hg}^{2+}(50)$ & 1.0 & 1.01 & $101 \pm 1.0$ \\
\hline & $+\mathrm{Se}^{\mathrm{IV}}(50)+\mathrm{Cu}(50)$ & 50 & 51.0 & $102 \pm 1.5$ \\
\hline \multirow{2}{*}{$\mathrm{D}$} & $\mathrm{As}$ in $\mathrm{C}+\mathrm{Sb}^{3+}(50)+\mathrm{Ni}^{2+}(50)+\mathrm{Ca}(50)$ & 1.0 & 1.02 & $102 \pm 1.6$ \\
\hline & $+\mathrm{Cd}(50)+\mathrm{Te}^{\mathrm{IV}}(50)$ & 50 & 50.5 & $101 \pm 1.0$ \\
\hline \multirow{2}{*}{ E } & As in $\mathrm{D}+\mathrm{Mg}(50)+\mathrm{Mn}^{\mathrm{VII}}(50)+\mathrm{W}^{\mathrm{VI}}(50)$ & 1.0 & 1.03 & $103 \pm 1.8$ \\
\hline & $+\mathrm{Ba}(50)+\mathrm{Ag}(50)$ & 50 & 51.5 & $103 \pm 1.5$ \\
\hline \multirow{2}{*}{$\mathbf{F}$} & As in $\mathrm{E}+\mathrm{Ce}^{\mathrm{III}}(50)+\mathrm{Na}(50)+\mathrm{K}(50)+$ & 1.0 & 1.05 & $105 \pm 2.1$ \\
\hline & $\mathrm{Zn}(50)+\mathrm{Ce}^{\mathrm{IV}}(50)$ & 50 & 52.5 & $105 \pm 2.0$ \\
\hline
\end{tabular}

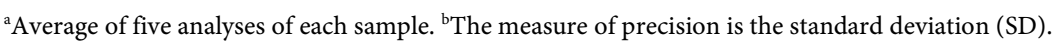


predict. Given that ring closure can lead to intense fluorescent in some circumstances, it seems likely that photo-oxidative cyclization takes place, leading to the formation of structure (A) in resonance with structure (B) (Figure 17).

\section{Applications}

The procedure was applied for determination of trace amounts of vanadium in some synthetic mixtures of various compositions (Table 4) and also in a number of real samples e.g. several Certified Reference Materials (CRMs) (Table 5). The method was also extended to the determination of vanadium in a number of environmental, biological, soil, food, vegetables and fruit samples. In view of the unknown composition of environmental water samples, the same equivalent portions of each such sample were analyzed for vanadium content; the recoveries in both the "spiked" (added to the samples before the mineralization or dissolution) and the "unspiked" samples are in excellent agreement (Table 6). The results of biological analyses by spectrofluorimetric method were found to be in excellent agreement with those obtained by ICP-OES (Table 7). The results of soil analyses by the spectrofluorimetric method were found to be in excellent agreement with those obtained by AAS (Table 8). The results of food analyses by spectrofluorimetric method were also found to be in excellent agreement with those obtained by ICP-OES (Table 9). The results of speciation of vanadium (IV) and vanadium (V) speciation in mixtures were highly reproducible (Table 10).

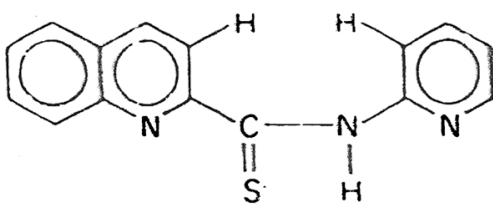

\section{2-( $\alpha$-pyridyl )thioquinaldinamide}

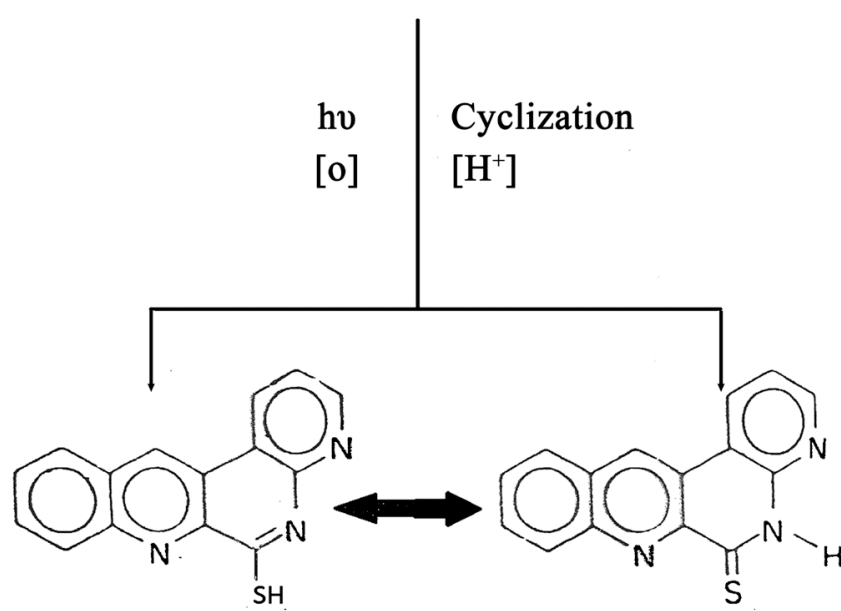

(A)

(B)

Figure 17. Mechanism of oxidative cyclization reaction of 2-( $\alpha$-pyridyl)-thioquinaldinamide (PTQA). 


\subsection{Determination of Vanadium in Synthetic Mixtures}

The procedure was applied to determine trace amounts of vanadium (V) in some synthetic mixtures with good recovery being achieved. The result indicates the proposed method is suitable and can be successfully applied for determination of $\mathrm{V}(\mathrm{V})$. Several synthetic mixtures of varying compositions containing vanadium $(\mathrm{V})$ and diverse ions of known concentrations were determined by the present method using EDTA as masking agent. The results were found to be highly reproducible as shown in Table 3 . Accurate recoveries were achieved in all solutions in the range $99.6 \pm 1.5$ to $99.9 \pm 0.6$. The reliability of our vanadium-PTQA oxidation procedure was approved by quantitative recovery of vanadium (V) spiked in several synthetic mixtures containing vanadium $(\mathrm{V})$ and diverse ions. This method has high precision and accuracy $\left(s= \pm 0.01\right.$ for $\left.0.5-\mu \mathrm{g} \cdot \mathrm{L}^{-1}\right)$.

\subsection{Determination of Vanadium in Some Certified Reference Materials}

A 0.1 -g amount of an alloy or steel sample containing $0.83 \%-1.99 \%$ of vanadium was weighed accurately and placed in a $50-\mathrm{mL}$ Erlenmeyer flask in presence of excess oxidizing agent to oxidize vanadium (IV) to vanadium (V) following a method recommended by Mitra [69]. To it, $10-\mathrm{mL}$ of $20 \%(\mathrm{w} / \mathrm{v})$ sulfuric acid was added and while carefully covering with a watch glass until the brisk reaction subsided. The solution was heated and simmered gently after the addition of $10-\mathrm{mL}$ of concentrated $\mathrm{HNO}_{3}$ until all residual carbides were decomposed. Then a further $2-\mathrm{mL}$ of $1+1 \mathrm{H}_{2} \mathrm{SO}_{4}$ and $2-\mathrm{mL} 2 \%(\mathrm{w} / \mathrm{v})$ freshly prepared ammonium persulphate were added and the solution was evaporated carefully to dense white fumes of sulphur trioxide, then cooled to room temperature $\left(25^{\circ} \mathrm{C} \pm\right.$ $5^{\circ} \mathrm{C}$ ). After suitable dilution with de-ionized water, the contents of the Erlenmeyer flask were warmed so as to dissolve the soluble salts. The solution was then cooled and neutralized with dilute $\mathrm{NH}_{4} \mathrm{OH}$ solution in presence of 1 - 2-mL of $0.01 \%(w / v)$ EDTA solution. The resulting solution was filtered if necessary, through a Whatman No. 40 filter paper into a $100-\mathrm{mL}$ calibrated flask. The residue (silica and tungstenic acid) was washed with a small volume of hot $1+99 \mathrm{H}_{2} \mathrm{SO}_{4}$, followed by water; the volume was made up to mark with de-ionized water.

An suitable liquot (1-2-mL) of the above-mentioned solution was taken into a $10-\mathrm{mL}$ calibrated flask and the vanadium $(\mathrm{V})$ content was determined; as described under procedure using tartrate or EDTA as masking agent. The proposed procedure for the spectrofluorimetric determination of vanadium was applied to the analysis of single element CRMs of V, estuarine sediment (CRM-MESS-3), Soil (CRM 029), human serum (CRM-ASTMRCVD-74231), Bovine liver (NIST@SRM-1577c) and drinking water (NIST-CRM-TMDW) the CRMs obtained from the National Research Council, Govt. of Canada, using tartrate or EDTA as masking agents, following a method recommended by Sun et al. [73]. Based on five replicate analyses, average vanadium concentration determined by the spectrofluorimetric method was in an excellent agreement with the certified 
values. The results are given in Table 5.

\subsection{Determination of Vanadium in Environmental Water Samples}

Each filtered (with Whatman No. 40) environmental sample (25-mL) contained in a 50-mL Pyrex beaker were added 1-mL of concentrated $\mathrm{H}_{2} \mathrm{SO}_{4}$ and 2-mL of concentrated $\mathrm{HNO}_{3}$ in the presence of freshly prepared excess ammonium persulphate solution in a fume cupboard to oxidize vanadium (IV) to vanadium (V) and the mixture was heated on a hot plate until white fumes of sulfur trioxide, following a method recommended by Greenberg et al. [74]. The solution was cooled and neutralized with dilute $\mathrm{NH}_{4} \mathrm{OH}$ solution in presence of $1-2-\mathrm{mL}$ of $0.01 \%(w / v)$ EDTA solution. Resulting solution was then filteredthrough a Whatman No. 40 filter paper and quantitatively transferred into a $25-\mathrm{mL}$ calibrated flask and made up to the mark with de-ionized water.

An aliquot $(1-2-\mathrm{mL})$ of this water sample was pipetted into a $10-\mathrm{mL}$ calibrated flask and the vanadium content was determined as described under the general procedure using tartrate or EDTA as masking agent. To test the validity of our method, we have analyzed different types of portable and polluted waters in spike and un-spike conditions. The reliability of our spectrofluorimetric method was tested by recovery studies. The average percentage recovery obtained for the addition of a vanadium (V) spike to some environmental water samples

Table 5. Determination of vanadium in some certified reference materials.

\begin{tabular}{|c|c|c|c|c|}
\hline \multirow[b]{2}{*}{ Sample no } & \multirow{2}{*}{$\begin{array}{l}\text { Certified Reference Materials } \\
\text { (Composition, \%) }\end{array}$} & \multicolumn{3}{|c|}{ Vanadium (\%) } \\
\hline & & $\begin{array}{l}\text { In C.R.M. } \\
\text { Sample }\end{array}$ & $\begin{array}{l}\text { Found } \\
(\mathrm{n}=5)\end{array}$ & $\mathrm{RSD}^{\mathrm{b}}$ \\
\hline 1 & $\begin{array}{l}\text { BAS-CRM-646: High-speed steel } \\
\text { (Cr, Mo, V and Tc) }\end{array}$ & 1.99 & 1.985 & 1.5 \\
\hline 2 & $\begin{array}{l}\text { BCS-CRM-220/L: High-speed steel } \\
(\mathrm{C}, \mathrm{Si}, \mathrm{S}, \mathrm{P}, \mathrm{Mn}, \mathrm{Mo}, \mathrm{V}, \mathrm{Cr}, \mathrm{Ni}, \mathrm{Co}, \mathrm{W} \text { and } \mathrm{Cu})\end{array}$ & 2.09 & 2.095 & 1.8 \\
\hline 3 & $\begin{array}{l}\text { BSC-CRM-241/L: High-speed steel } \\
\text { (Cr, V, W, Co, Mo, Mn, C, Si, P and S) }\end{array}$ & 1.57 & 1.578 & 1.5 \\
\hline 4 & $\begin{array}{l}\text { GSBH-40101-96: } \mathrm{Cr}_{12} \mathrm{MoV} \text { : Dies steel } \\
(\mathrm{Cr}, \mathrm{Mo}, \mathrm{V}, \mathrm{Ni}, \mathrm{Cu}, \mathrm{Co})\end{array}$ & 0.411 & 0.410 & 2.0 \\
\hline 5 & $\begin{array}{l}\text { YSBC-1013-1-95: } 9 \mathrm{Cr}_{17} \mathrm{MoVCo} \text { : } \\
\text { High-tensil steel (C, } \mathrm{Cr}, \mathrm{Mo}, \mathrm{V}, \mathrm{Si}, \mathrm{Mn} \text { and } \mathrm{Co})\end{array}$ & 0.24 & 0.25 & 2.5 \\
\hline 6 & $\begin{array}{l}\text { CRM-ASTMRCVD-74231: Human Serum } \\
\text { (Quest-Diagonisstics, ISO-17025) }\end{array}$ & $0.83^{\mathrm{e}}$ & 0.81 & 1.0 \\
\hline 7 & $\begin{array}{l}\text { CRM 029: Sigma-Aldrich: Soil } \\
\text { (ISO/17025) }\end{array}$ & $71.0^{\mathrm{d}}$ & 70.5 & 1.8 \\
\hline 8 & CRM-MESS-3: Sediments & $234 \pm 10^{c}$ & $233 \pm 3.0$ & 2.0 \\
\hline 9 & NIST@SRM-1577c-Bovine liver & $8.17 \pm 0.66^{\mathrm{d}}$ & $8.15 \pm 0.5$ & 2.0 \\
\hline 10 & NIST-CRM-TMDW: Drinking water & $30.0^{\mathrm{f}}$ & 29.8 & 1.5 \\
\hline
\end{tabular}

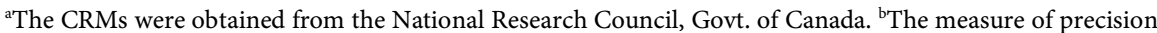
is the relative standard deviation(RSD). ${ }^{c}$ Values in $\mu \mathrm{g} \cdot \mathrm{g}^{-1},{ }^{\mathrm{d}} \mathrm{V}$ alues in $\mathrm{mg} \cdot \mathrm{kg}^{-1}$. ${ }^{\mathrm{e}} \mathrm{V}$ alues in $\mu \mathrm{g} \cdot \mathrm{kg}^{-1},{ }^{\mathrm{f}} \mathrm{Values}$ in $\mu \mathrm{g} \cdot \mathrm{L}^{-1}$. 
was quantitative. The results of analyses of environmental water samples from various sources for vanadium are shown in Table 6.

Table 6. Determination of vanadium in some environmental water samples.

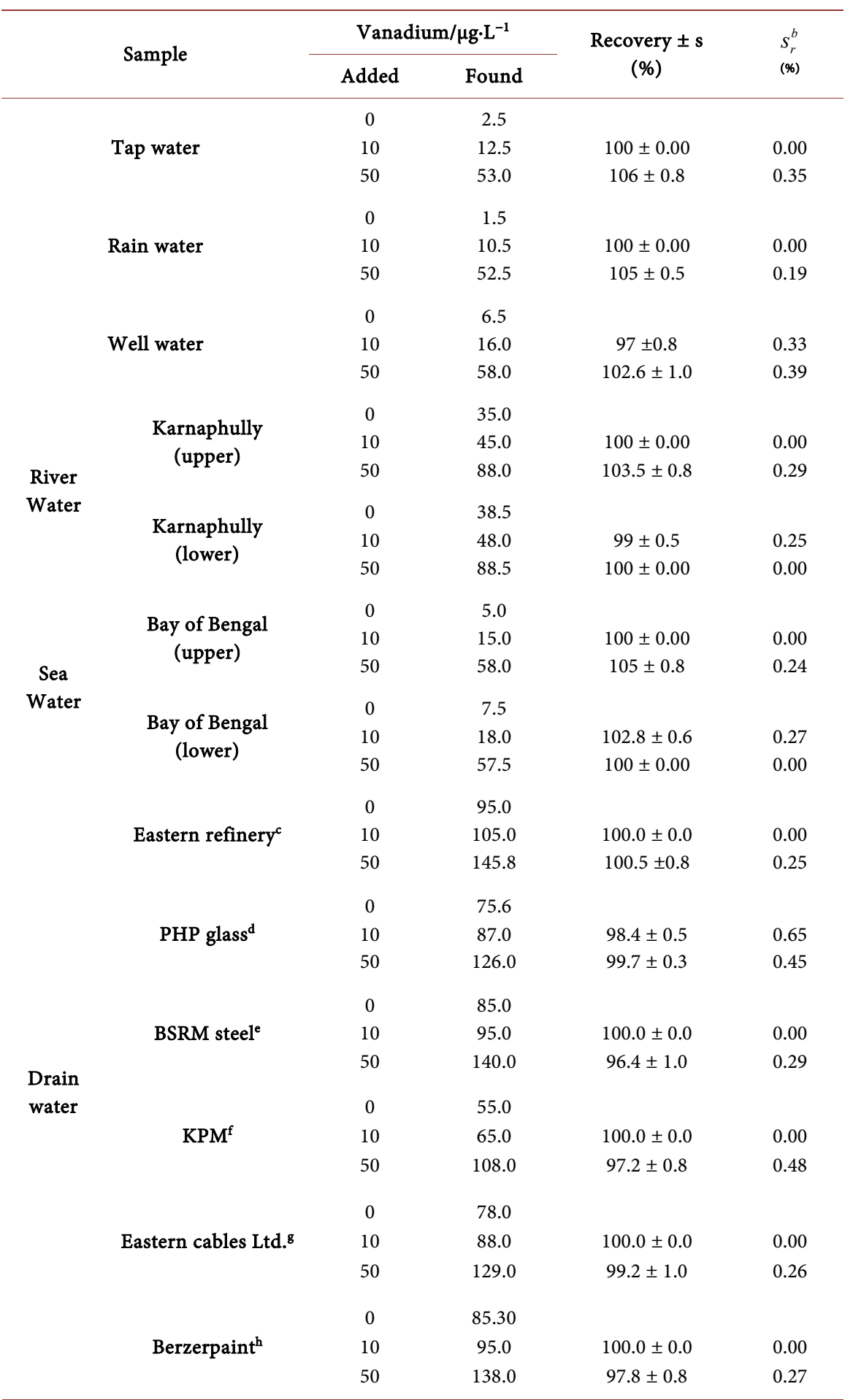

${ }^{a}$ Average of five replicate determinations of each sample. ${ }^{\text {}}$ The measure precision is the relative standard deviation. ${ }^{~}$ Eastern Refinary Patenga, Chittagong. ${ }^{\mathrm{d}}$ PHP Glass factory, Chittagong. ${ }^{e}$ Bangladesh Steel Re-rolling Mills Ltd. (BSRM), Baizid Bosthami, Chittagong. ${ }^{\mathrm{f} K a r n a p h u l l y ~ P a p e r ~ M i l l s, ~ C h a n d r a g h o n a, ~ C h i t t a g o n g . ~}{ }^{\mathrm{g} E}$ Eastern

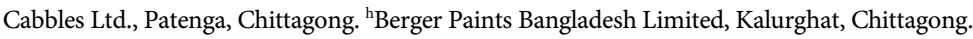


Most spectrofluorimetric methods for determination of vanadium in natural and sea-water require preconcentration or standard addition of vanadium [75]. The concentration of vanadium in natural and sea water is a few $\mu \mathrm{g} \cdot \mathrm{L}^{-1}$ in Japan [76]. The mean concentration of vanadium found in US drinking waters is $6-\mu \mathrm{g} \cdot \mathrm{L}^{-1}[75]$.

\subsection{Determination of Vanadium in Biological Samples}

Human blood or milk (2 - 3-mL) or urine (10 - 20-mL) or hair (3 - 5-g) sample was taken into a $100-\mathrm{mL}$ micro-Kjeldahl flask. A glass bead and $10-\mathrm{mL}$ of concentrated nitric acid were added, and the flask was placed on the digester under gentle heating. The sample was digested in the presence of an excess freshly prepared ammonium persulphate solution $(2-\mathrm{mL}$ of $2 \% \mathrm{w} / \mathrm{v})$ to oxidize vanadium (IV) to vanadium (V) according to the method recommended by Stahr [77]. As the heating process continued 1- $\mathrm{mL}$ of $\mathrm{H}_{2} \mathrm{SO}_{4}$ is added and heated for about 0.5 hour to dense white fumes of sulphur trioxide. When the initial brisk reaction was completed, the solution was removed and cooled at room temperature and neutralized with dilute $\mathrm{NH}_{4} \mathrm{OH}$ solution in presence of $1-2-\mathrm{mL}$ of $0.01 \%(\mathrm{w} / \mathrm{v})$ EDTA solution. Resulting solution was then filteredthrough a What-man No. 40 filter paper and quantitatively transferred into a $25-\mathrm{mL}$ calibrated flask and made up to the mark with de-ionized water.

A suitable aliquot $(1-2-\mathrm{mL})$ of the final solution was pipetted out into a $10-\mathrm{mL}$ calibrated flask and the vanadium content was determined as described under the general procedure using EDTA or tartrate as masking agent. The results of biological analyses by the spectrofluorimetric method were found to be in excellent agreement with those obtained by ICP-OES. The results are shown in Table 7.

The abnormally high values for the human lung cancer patient are probably due to the involvement of high vanadium concentration with As and $\mathrm{Zn}$. The occurrence of such high vanadium contents are also reported in lung cancer patients from some developed countries [78]. The low value for the heart-disease patient is probably due to a low vanadium concentration in the environment. There is an inverse correlation between human heart-disease and vanadium concentration in the environment [79].

\subsection{Determination of Vanadium in Some Surface Soil Samples}

An air-dried homogenized soil sample (10-g) was accurately weighed and placed in a $100-\mathrm{mL}$ micro-Kjeldahl flask. The sample was digested in the presence of an excess oxidizing agent (2-mL of $2 \%$ freshly prepared ammonium persulfate solution) to oxidize vanadium (IV) to vanadium (V) following method recommended by Jackson [80]. As the heating process continued 1-mL of $\mathrm{H}_{2} \mathrm{SO}_{4}$ is added and heated for about 5 minutes to dense white fumes of sulphur trioxide. The solution was then cooled at room temperature and neutralized with dilute $\mathrm{NH}_{4} \mathrm{OH}$ solution in presence of $1-2-\mathrm{mL}$ of $0.01 \%(\mathrm{w} / \mathrm{v})$ EDTA solution. The content of 
Table 7. Determination of vanadium in some human fluids and hair sample.

\begin{tabular}{|c|c|c|c|c|c|c|}
\hline \multirow{3}{*}{$\begin{array}{l}\text { Serial } \\
\text { No. }\end{array}$} & \multirow{3}{*}{ Sample } & \multicolumn{4}{|c|}{ Vanadium $/ \mu \mathrm{g} \cdot \mathrm{L}^{-1}$} & \multirow{3}{*}{ Sample Source ${ }^{a}$} \\
\hline & & \multicolumn{2}{|c|}{$\begin{array}{c}\text { ICP-OES } \\
(n=5)\end{array}$} & \multicolumn{2}{|c|}{$\begin{array}{l}\text { Proposed Method } \\
\qquad(\mathrm{n}=5)\end{array}$} & \\
\hline & & Found & RSD (\%) & Found & RSD (\%) & \\
\hline \multirow{2}{*}{1} & Blood & 15.0 & 1.5 & 15.5 & 1.5 & \multirow{2}{*}{$\begin{array}{l}\text { Heart disease patient } \\
\text { (Female) }\end{array}$} \\
\hline & Urine & 5.8 & 1.2 & 5.9 & 1.3 & \\
\hline \multirow{2}{*}{2} & Blood & 225.5 & 2.5 & 228.0 & 2.0 & \multirow{2}{*}{$\begin{array}{l}\text { Liver cirrhosis patient } \\
\text { (Male) }\end{array}$} \\
\hline & Urine & 57.8 & 1.8 & 58.5 & 1.5 & \\
\hline \multirow{2}{*}{3} & Blood & 361.0 & 2.8 & 368.0 & 2.5 & \multirow{2}{*}{$\begin{array}{l}\text { Lung cancer patient } \\
\text { (Male) }\end{array}$} \\
\hline & Urine & 95.0 & 1.8 & 96.5 & 1.7 & \\
\hline \multirow{2}{*}{4} & Blood & 209.0 & 2.6 & 211.5 & 2.2 & \multirow{2}{*}{$\begin{array}{c}\text { Kidney damage patient } \\
\text { (Female) }\end{array}$} \\
\hline & Urine & 53.0 & 1.7 & 55.5 & 1.8 & \\
\hline \multirow{2}{*}{5} & Blood & 132.5 & 2.0 & 135.0 & 2.0 & \multirow{2}{*}{$\begin{array}{l}\text { Skin disease patient } \\
\text { (Female) }\end{array}$} \\
\hline & Urine & 34.0 & 1.5 & 35.5 & 1.8 & \\
\hline \multirow{2}{*}{6} & Blood & 18.0 & 2.2 & 18.5 & 2.0 & \multirow{2}{*}{$\begin{array}{l}\text { Manic disease patient } \\
\text { (Male) }\end{array}$} \\
\hline & Urine & 5.0 & 1.5 & 4.8 & 1.4 & \\
\hline \multirow{2}{*}{7} & Blood & 8.0 & 2.0 & 10.5 & 1.8 & \multirow{2}{*}{$\begin{array}{l}\text { Diabetic patient } \\
\text { (Male) }\end{array}$} \\
\hline & Urine & 2.0 & 1.3 & 2.5 & 1.0 & \\
\hline \multirow{2}{*}{8} & Blood & 10.0 & 1.8 & 12.0 & 1.5 & \multirow{2}{*}{$\begin{array}{l}\text { Normal Adult } \\
\text { (Female) }\end{array}$} \\
\hline & Urine & 3.0 & 1.5 & 3.5 & 1.3 & \\
\hline 9 & Hair sample & $100.0^{\mathrm{b}}$ & 1.5 & 103.0 & 1.6 & $\begin{array}{l}\text { Human hair } \\
\text { (Female) }\end{array}$ \\
\hline 10 & Milk & $5.0^{\mathrm{b}}$ & 0.8 & 6.0 & 1.0 & Lactating Mother \\
\hline
\end{tabular}

${ }^{\mathrm{a} S}$ Samples were collected from Chittagong Medical College Hospital; ${ }^{\mathrm{b}}$ Values in $\mu \mathrm{g} \cdot \mathrm{g}^{-1}$.

the flask was then filtered through a What-man No. 40 filter paper and quantitatively transferred into a $25-\mathrm{mL}$ calibrated flask and made up to the mark with de-ionized water.

A suitable aliquot $(1-2-\mathrm{mL})$ of the final solution was pipetted out into a $10-\mathrm{mL}$ calibrated flask and the vanadium content was determined as described under the general procedure using tartrate or EDTA as masking agent. The vanadium content was then determined by the above procedure and quantified from a calibration graph prepared concurrently. The results of soil analyses by spectrofluorimetric method were also found to be in excellent agreement with those obtained by AAS. The average value of vanadium in the Chittagong region surface soil was found to be $53.27-\mu \mathrm{g} \cdot \mathrm{kg}^{-1}$. The results are shown in Table 8 .

\subsection{Determination of Vanadium in Some Vegetable, Food and Fruit Samples}

The vegetable and fruit samples collected prior to the determination were 
Table 8. Determination of vanadium in some surface soil samples.

\begin{tabular}{|c|c|c|c|c|}
\hline \multirow[b]{2}{*}{ Serial No. } & \multicolumn{3}{|c|}{ Vanadium $/ \mu \mathrm{g} \cdot \mathrm{kg}^{-1}$} & \multirow[b]{2}{*}{ Sample Sources ${ }^{c}$} \\
\hline & $\operatorname{AAS}(n=5)$ & $\begin{array}{l}\text { Proposed method } \\
\quad(n=5)\end{array}$ & $\operatorname{RSD}^{\mathrm{b}}(\%)$ & \\
\hline $\mathrm{S}_{1}$ & 52.0 & 51.8 & 1.5 & $\begin{array}{c}\text { Esturine soil (Sediment) } \\
\text { (River Karnaphully Chittagong) }\end{array}$ \\
\hline $\mathrm{S}_{2}$ & 20.0 & 19.8 & 1.0 & $\begin{array}{c}\text { Marine soil } \\
\text { (Bay of Bengal) }\end{array}$ \\
\hline $\mathrm{S}_{3}$ & 36.0 & 35.8 & 1.2 & $\begin{array}{l}\text { Clevendon Tea Estate } \\
\text { (Moulabi Bazar, Sylhet) }\end{array}$ \\
\hline $\mathrm{S}_{4}$ & 13.0 & 12.5 & 1.0 & $\begin{array}{c}\text { Agricultural soil } \\
\text { (Chittagong university campuse) }\end{array}$ \\
\hline $\mathrm{S}_{5}$ & 46.5 & 45.6 & 1.5 & $\begin{array}{l}\text { Industrial soil } \\
\text { (Berger paint) }\end{array}$ \\
\hline $\mathrm{S}_{6}$ & 160.0 & 157.5 & 1.8 & $\begin{array}{c}\text { Industrial soil } \\
\text { (Eastern Refineries) }\end{array}$ \\
\hline $\mathrm{S}_{7}$ & 58.0 & 56.8 & 1.6 & $\begin{array}{l}\text { Industrial sol } \\
\text { (Eastern Cable) }\end{array}$ \\
\hline $\mathrm{S}_{8}$ & 67.0 & 65.5 & 1.8 & $\begin{array}{l}\text { Industrial soil } \\
\text { (PHP glass) }\end{array}$ \\
\hline$S_{9}$ & 32.5 & 31.8 & 1.2 & $\begin{array}{c}\text { Industrial soil } \\
\text { (Ship-breaking area) }\end{array}$ \\
\hline$S_{10}$ & 57.0 & 1.5 & 1.5 & $\begin{array}{c}\text { Industrial soil } \\
\text { (BSRM Steel Mill) }\end{array}$ \\
\hline
\end{tabular}

${ }^{a}$ Average of five analyses of each sample. ${ }^{\text {b}} \mathrm{The}$ measure of precision is the relative standard deviation (RSD). 'Composition of the soil samples: $\mathrm{C}, \mathrm{N}, \mathrm{P}, \mathrm{K}, \mathrm{Na}, \mathrm{Ca}, \mathrm{Mg}, \mathrm{Ce}, \mathrm{Cu}, \mathrm{Mo}, \mathrm{Fe}, \mathrm{Pb}, \mathrm{V}, \mathrm{Zn}, \mathrm{Mn}, \mathrm{Co}, \mathrm{NO}_{3}, \mathrm{SO}_{4}$ et al.

pretreated in the following way: Edible portion of samples was first washed clean with tap water followed by rewashing with de-ionized water. After removing de-ionized water from the surface of vegetables and fruits, the samples were cut into small pieces and dried at $65^{\circ} \mathrm{C}$ in oven. An air dried vegetables and fruits samples (10-g) were ground in a mortar and taken in a $100-\mathrm{mL}$ micro-Kjeldahl flask in presence of excess oxidizing agent and digested following a method recommended by Stahr [77] and 10-mL of concentrated nitric acid were added and the flask was placed on the digester under gentle heating. When the initial brisk reaction was over, the solution was removed and cooled at room temperature. 1-mL volume of concentrated sulfuric acid was added carefully, followed by the addition of $2-\mathrm{mL}$ of concentrated $\mathrm{HF}$, and heating was continued for at least $1 / 2 \mathrm{hr}$ and then cooled. In the resulting solution $2-\mathrm{mL}$ of $2 \%(\mathrm{w} / \mathrm{v})$ of freshly prepared ammonium persulfate is added. The mixture of each foodstuff was heated below the boiling point for $5-10 \mathrm{~min}$ to oxidize vanadium (IV) to vanadium (V). The solutions were then cooled and neutralized with dilute $\mathrm{NH}_{4} \mathrm{OH}$ in presence of 1 - 2-mL of $0.01 \%(\mathrm{w} / \mathrm{v})$ EDTA solution. The resulting solution was filtered through a Whatman No. 40 filter paper and quantitatively transferred into a $25-\mathrm{mL}$ calibrated flask and mixed well and made up to the mark with de-ionized 
water.

The food samples used were rice, wheat and corn and these were used under dry conditions. Each sample was first ground in a mortar. Corn and fruit samples (2-g) or rice and wheat samples (1-g) were weighed accurately and placed in a porcelain crucible and charred in an electric furnace; the sample was ashen at $555^{\circ} \mathrm{C}$ in a muffle furnace in presence of excess oxidizing agent following a method recommended by Mitra [69]. To it, 2.0-mL of $\mathrm{HCl}$ and $10-\mathrm{mL}$ of water were added to the ash. The mixture of each foodstuff was heated with $2-\mathrm{mL}$ of $2 \%(\mathrm{w} / \mathrm{v})$ freshly prepared ammonium persulphate was added below the boiling point for 5 - 10 min to complete oxidation from $\mathrm{V}(\mathrm{IV})$ to $\mathrm{V}(\mathrm{V})$. The solutions were cooled and neutralized with dilute $\mathrm{NH}_{4} \mathrm{OH}$ in presence of 1 - 2-mL of $0.01 \%(\mathrm{w} / \mathrm{v})$ EDTA solution and filtered. The resulting solution was quantitatively transferred into a $25-\mathrm{mL}$ calibrated flask and mixed well and made up to the mark with de-ionized water.

A suitable aliquot $(1-2-\mathrm{mL})$ of the final digested solution was pipetted into a $10-\mathrm{mL}$ calibrated flask and the vanadium content was determined as described under the general procedure using tartrate as masking agent. High value of vanadium for Daucuscarota (carrot) is probably due to the involvement of high vanadium concentration in the soil. Such a high concentration of vanadium in carrot and radish is also reported in some developed countries [81]. The results of food and vegetables analyses by spectrofluorimetric method were also found to be in excellent agreement with those obtained by ICP-OES. The results are shown in Table 9.

\subsection{Determination of Vanadium (IV) and Vanadium (V) Speciation in Mixtures}

Suitable aliquots $(1-2-\mathrm{mL})$ of vanadium $(\mathrm{V}+\mathrm{IV})$ mixtures (preferably 1:1, 1:5, 1:10) were taken in a 250-mL Pyrex conical flask. A few drops (3 - 5 drops) of 4 $\mathrm{M} \mathrm{H}_{2} \mathrm{SO}_{4}$, and 5 - $10-\mathrm{mL}$ of $2 \%$ (w/v) freshly prepared ammonium persulphate were added to oxidize tetravalent vanadium to pentavalent vanadium and the mixture was heated gently with further addition of $10-\mathrm{mL}$ water, if necessary, for 5 minutes to drive off the excess persulphate, then the mixture was cooled to room temperature $(25 \pm 5)^{\circ} \mathrm{C}$. The reaction mixture was then cooled and neutralized with dilute $\mathrm{NH}_{4} \mathrm{OH}$ in presence of $3-5-\mathrm{mL}$ of $0.01 \%(\mathrm{w} / \mathrm{v})$ EDTA solution. The solution was transferred quantitatively into a $25-\mathrm{mL}$ volumetric flask and 3.75-mL of $3.77 \times 10^{-3}$ M PTQA reagent solution was added followed by the addition of $2.5-\mathrm{mL}$ of $0.05 \mathrm{M} \mathrm{H}_{2} \mathrm{SO}_{4}$. It was made up to the mark with de-ionized water. The fluorescence intensity was measured then being cooled at room temperature, $(25 \pm 5)^{\circ} \mathrm{C}$, at $371 \mathrm{~nm}$ when excited at $319 \mathrm{~nm}$, against a reagent blank. The total vanadium content was calculated with the help of a calibration graph prepared concurrently.

An equal aliquot $(1-2-\mathrm{mL})$ of the above vanadium $(\mathrm{V}+\mathrm{IV})$ mixture was taken into a 250-mL Pyrex conical flask. The solution was neutralized with dilute 
Table 9. Determination of vanadium in some food, fruit and vegetable samples.

\begin{tabular}{|c|c|c|c|c|c|c|}
\hline \multirow{3}{*}{$\begin{array}{c}\text { Serial } \\
\text { No. }\end{array}$} & \multirow{3}{*}{ Sample } & \multicolumn{4}{|c|}{ Vanadium $/ \mu \mathrm{g} \cdot \mathrm{kg}^{-1}$ Found $^{\mathrm{a}} \pm s(\mathrm{n}=5)$} & \multirow{3}{*}{ Sample Source } \\
\hline & & \multicolumn{2}{|c|}{ ICP-OES $(n=5)$} & \multicolumn{2}{|c|}{ Proposed Method $(n=5)$} & \\
\hline & & Found & $\mathrm{RSD}^{\mathrm{b}} \%$ & Found & $\operatorname{RSD}^{\mathrm{b}} \%$ & \\
\hline 1 & Ginger (Zingiber officinale) & 175.0 & 1.6 & 179.0 & 1.8 & Local Market, Chittagong \\
\hline 2 & Carrot (Daucus carota) & 180.0 & 1.8 & 183.0 & 2.0 & Local Market, Chittagong \\
\hline 3 & Garlic (Allium sativum) & 145.0 & 1.9 & 148.5 & 2.0 & Local Market, Chittagong \\
\hline 4 & Onion (Allium cepa) & 80.0 & 1.0 & 82.8 & 1.3 & Local Market, Chittagong \\
\hline 5 & Tomato (Lycopersicon esculentum) & 100.0 & 1.2 & 105.0 & 1.5 & Local Market, Chittagong \\
\hline 6 & White cabbage (Brassica oleracea capitata) & 535.0 & 2.0 & 538.0 & 2.0 & Local Market, Chittagong \\
\hline 7 & Radish (Raphanus sativus) & 165.8 & 1.5 & 170.0 & 1.7 & Local Market, Chittagong \\
\hline 8 & Rice (Oryza sativa) & 25.0 & 1.3 & 24.8 & 1.5 & Local Market, Chittagong \\
\hline 9 & Tea (Camellia sinensis) & 16.8 & 2.3 & 18.5 & 2.5 & Local Market, Chittagong \\
\hline 10 & Wheat (Triticum aestivum) & 35.0 & 1.5 & 38.0 & 1.6 & Local Market, Chittagong \\
\hline 11 & Shellfish & 100.0 & 1.5 & 103.0 & 1.5 & Local Market, Chittagong \\
\hline 12 & Milk (Cow milk) & $30.0^{\mathrm{c}}$ & 1.5 & $31.5^{\mathrm{c}}$ & 1.6 & Local Market, Chittagong \\
\hline 13 & Mushrooms (Agaricus bisporus) & 431.0 & 1.8 & 435.0 & 2.0 & Local Market, Chittagong \\
\hline
\end{tabular}

${ }^{a}$ Average of five replicate analyses of each sample. ${ }^{b}$ The measure of precision is the relative standard deviation (RSD). ${ }^{c}$ Values in $\mu g \cdot L^{-1}$.

$\mathrm{NH}_{4} \mathrm{OH}$ in presence of $3-5-\mathrm{mL}$ of $0.01 \%(\mathrm{w} / \mathrm{v})$ EDTA solution. After, the content of the beaker was transferred quantitatively into a $25-\mathrm{mL}$ volumetric flask, $3.75-\mathrm{mL}$ of $3.77 \times 10^{-3} \mathrm{M}$ PTQA reagent solution was added, followed by the addition of $2.5-\mathrm{mL}$ of $0.05 \mathrm{M} \mathrm{H}_{2} \mathrm{SO}_{4}$. It was made up to the mark with de-ionized water. After $5 \mathrm{~min}$ the fluorescence intensity was measured following the general procedure at $371 \mathrm{~nm}$ when excited at $319 \mathrm{~nm}$ against a reagent blank, as before. The vanadium concentration was calculated in $\mu \mathrm{g} \cdot \mathrm{L}^{-1}$ or $\mathrm{ng} \cdot \mathrm{L}^{-1}$ with the aid of a calibration graph. This gives a measure of vanadium (V) originally present in the mixture. This value was subtracted from that of the total vanadium to determine the vanadium (IV) present in the mixture. The results of the assessment of speciation of $\mathrm{V}(\mathrm{V})$ and $\mathrm{V}$ (IV) were found to be highly reproducible. The occurrence of such reproducible results is also reported for different oxidation states of vanadium [82]. The results of a set of determination are given in Table 10 .

\section{Conclusions}

A new simple rapid, ultra-sensitive, highly selective and inexpensive spectrofluorimetric method with the vanadium-PTQA system was developed for the determination of vanadium in some real, environmental, biological, food, vegetables and soil samples. Compared with other existing methods [35]-[60], the proposed method has several remarkable analytical characteristics: 
Table 10. Determination of vanadium (V) and vanadium (IV) in mixtures.

\begin{tabular}{|c|c|c|c|c|c|c|c|}
\hline \multirow[t]{2}{*}{ Serial No. } & \multirow[t]{2}{*}{ V (V):V (IV) } & \multicolumn{2}{|c|}{$\begin{array}{l}\mathrm{V}, \text { taken } \\
\left(\mu \mathrm{g} \cdot \mathrm{L}^{-1}\right)\end{array}$} & \multicolumn{2}{|c|}{$\begin{array}{l}V, \text { found } \\
\left(\mu \mathrm{g} \cdot \mathrm{L}^{-1}\right)\end{array}$} & \multicolumn{2}{|c|}{$\begin{array}{c}\text { Error } \\
\left(\mu \mathrm{g} \cdot \mathrm{L}^{-1}\right)\end{array}$} \\
\hline & & $\mathrm{V}(\mathrm{V})$ & $\mathrm{V}(\mathrm{IV})$ & $\mathrm{V}(\mathrm{V})$ & $\mathrm{V}(\mathrm{IV})$ & $\mathrm{V}(\mathrm{V})$ & $\mathrm{V}(\mathrm{IV})$ \\
\hline 1 & $1: 1$ & 10 & 10 & 9.99 & 9.98 & 0.01 & 0.02 \\
\hline 1 & $1: 1$ & 10 & 10 & 10.0 & 9.98 & 0.00 & 0.02 \\
\hline \multirow[t]{2}{*}{1} & $1: 1$ & 10 & 10 & 9.98 & 10.0 & 0.02 & 0.00 \\
\hline & \multicolumn{3}{|c|}{ Standard deviation: $\mathrm{V}(\mathrm{V})= \pm 0.0058$} & \multicolumn{2}{|c|}{$\mathrm{V}(\mathrm{IV})= \pm 0.011$} & & \\
\hline 1 & $1: 5$ & 10 & 50 & 9.99 & 49.98 & 0.01 & 0.02 \\
\hline 1 & $1: 5$ & 10 & 50 & 9.98 & 49.98 & 0.02 & 0.02 \\
\hline \multirow[t]{3}{*}{1} & $1: 5$ & 10 & 50 & 9.99 & 49.99 & 0.01 & 0.01 \\
\hline & \multicolumn{3}{|c|}{ Mean error: $V(V)= \pm 0.013$} & \multicolumn{2}{|c|}{$\mathrm{V}(\mathrm{IV})= \pm 0.016$} & & \\
\hline & \multicolumn{3}{|c|}{ Standard deviation: $\mathrm{V}(\mathrm{V})= \pm 0.0058$} & \multicolumn{2}{|c|}{$\mathrm{V}(\mathrm{IV})= \pm 0.006$} & & \\
\hline 1 & $1: 10$ & 10 & 100 & 10.00 & 99.99 & 0.00 & 0.01 \\
\hline 1 & $1: 10$ & 10 & 100 & 9.98 & 99.98 & 0.02 & 0.02 \\
\hline \multirow[t]{3}{*}{1} & $1: 10$ & 10 & 100 & 9.98 & 99.98 & 0.02 & 0.02 \\
\hline & \multicolumn{3}{|c|}{ Mean error: $V(V)= \pm 0.015$} & \multicolumn{2}{|c|}{$\mathrm{V}(\mathrm{IV})= \pm 0.016$} & & \\
\hline & \multicolumn{3}{|c|}{ Standard deviation: $\mathrm{V}(\mathrm{V})= \pm 0.005$} & \multicolumn{2}{|c|}{$\mathrm{V}(\mathrm{IV})= \pm 0.006$} & & \\
\hline
\end{tabular}

1) The proposed method is highly sensitive that the amount, in ng. $\mathrm{L}^{-1}$, of vanadium can be determined without any preconcentration or standard addition in diluted biological and environmental solutions.

2) The low detection limit, $0.3-\mathrm{ng} \cdot \mathrm{L}^{-1}$ i.e. $\mathrm{pg} \cdot \mathrm{g}^{-1}\left(10^{-12} \mathrm{~g}\right)$ or $\mathrm{pg} \cdot \mathrm{mL}^{-1}$ levels can be measured without preconcentration or standard addition technique.

3) The method has added advantages of determining individual amounts of vanadium (IV) and vanadium (V).

With suitable masking agents, the reaction can be made highly selective and better reproducibility has been achieved (RSD $=0 \%-2 \%$ ).

Although many sophisticated techniques such as pulse polarography, High Performance Liquid Chromatography (HPLC), Atomic absorption spectroscopy (AAS), Inductively coupled plasma optical emission spectrometry (ICP-OES) and Inductively coupled plasma mass spectrometry (ICP-MS), are available for the determination of vanadium at trace levels in numerous complex materials, factors such as the low cost of the instrument, easy handling, lack of requirement for consumables and almost no maintenance have caused spectrofluorimetry to remain a popular technique, particularly in laboratories of developing countries with limited budgets.

The sensitivity and precision in terms of relative standard deviation of the present method are very reliable for the determination of vanadium in real samples down to $\mathrm{pg} \cdot \mathrm{g}^{-1}\left(10^{-12} \mathrm{~g} \cdot \mathrm{g}^{-1}\right)$ levels in aqueous medium at room temperature $(25 \pm 5)^{\circ} \mathrm{C}$. It is a new method needs neither heating nor extraction to organic phase, works satisfactorily and could be an alternative method for the rapid de- 
termination of vanadium in a wide variety of sample matrices and found superior to existing spectrofluorimetric methods reported in different literature [35]-[60].

\section{Acknowledgements}

We are thankful to the Authorities of Chittagong Medical College Hospital and Chittagong Treatment Hospital for supplying biological samples. We are also thankful to the Authorities of BNO Lubricants, Chittagong to permit me for analyzing Biological, Food and Pharmaceutical Samples by ICP-OES. We are also grateful to the Department of Chemistry, University of Chittagong for providing me all the logistic supports for completion of my Research Work.

\section{Conflicts of Interest}

All authors report no conflicts of interest relevant to this article.

\section{References}

[1] Trivino, S., Diaz, A., et al. (2019) Vanadium in Biological Action: Chemical, Pharmacological Aspects and Metabolic Implications in Diabetes Mellitus. Biological Trace Elements Research, 188, 68-98. https://doi.org/10.1007/s12011-018-1540-6

[2] Ostrooumov, M. and Taran, Y. (2015) Discovery of Native Vanadium, a New Mineral from the Colima Volcano, State of Colima (Mexico). Revista de la Sociedad Española de Mineralogía, 20, 109-115.

[3] https://en.wikipedia.org/wiki/vanadium

[4] Clayton, G.D. and Clayton, F.E. (1981) Patty's Industrial Hygiene and Toxicology. 3rd Edition, Wiley, New York, 2013-2035.

[5] Hurley, L.S., Bratter, P., Schramel, P. and Gruyter, W. (1984) Trace Element Analytical Chemistry in Medicine and Biology. Walter de Gruyter, Berlin, Vol. 3, 375-386.

[6] Mracova, A., Jirova, D., Janci, H. and Lener, J. (1993) Spectrophotometric Method for Determination of Vanadium and Its Application to Industrial, Environmental Biological and Soil Samples. Science of the Total Environment, 1, E16/633.

[7] Key, M.M., Henschel, A.F., Butter, J., Ligo, R.N. and Tabershad, I.R. (1977) Occupational Diseases: A Guide to Their Recognition. US Department of Health, Education and Welfare, US Government Printing, Washington DC.

[8] Shamberger, R.J., Gunsch, M.S., Willis, C.F. and McCormack, I.J. (1978) Trace Substances in Environmental Health XII. University of Missouri, Columbia.

[9] Grans, D.C., Gottlieb, M., Tawara, J., Bunch, R.L. and Thiesen, L.A. (1990) A Kinetic Method for Determination of Free Vanadium (IV) and (V) at Trace Level Concentrations. Analytical Biochemistry, 188, 53-59. https://doi.org/10.1016/0003-2697(90)90527-G

[10] Balaji, B.K., Saravanakumar, G., Murugesan, P. and Mishra, G. (1998) A Modified Catalytic-Photometric Method for the Determination of Vanadium in Chloride Rich Hydro-Geochemical Samples. Talanta, 46, 1299-1306. https://doi.org/10.1016/S0039-9140(97)00397-4

[11] Venugopal, B. and Luckey, T.D. (1979) Metal Toxicity in Mammals. Plenum Press, New York, Vol. 2, 220-230. 
[12] Langard, S., Norseth, T., Friberg, L., Nordberg, G.F. and Vouk, V.B. (1986) Handbook on the Toxicology of Metals. In: Friberg, L., Nordberg, G.F. and Vouk, V.B., Eds., Elsevier, Amsterdam, 322-345.

[13] Liao, Z.J. (1989) Pollution, Hazard, Migrate and Transform of Micro Amounts Heavy Metal Elements in Environment. Science Press, Beijing, 28-40.

[14] Patel, B., Henderson, V.S., Haswell, J. and Grzeskowiak, R. (1990) Speciation of Vanadium Present in a Model Yeast System. Analyst, 115, 1063-1069. https://doi.org/10.1039/an9901501063

[15] Nelson, W.L. (1973) Biochemical Changes after Acetaminophen-Induced and Furosemide-Induced Liver Injury. Oil \& Gas Journal, 71, 54-61.

[16] Kiriyana, T. and Kuroda, R. (1972) A Combined Ion-Exchange-Spectrophotometric Determination of Vanadium in Sea and Natural Waters. Analytica Chimica Acta, 62, 464-472. https://doi.org/10.1016/0003-2670(72)80060-6

[17] Kiran, T.N.K. and Revanasiddappa, H.D. (2005) Spectrophotometric Determination of Vanadium Using Variamine Blue and Its Application to Synthetic, Environmental and Biological Samples. Journal of the Iranian Chemical Society, 2, 161-169. https://doi.org/10.1007/BF03247208

[18] Rostampour, L. and Ali, T.M. (2008) Determination of Trace Amounts of Vanadium by UV-Vis Spectrophotometric after Separation and Preconcentration with Modified Natural Clinoptilolite as a New Sorbent. Talanta, 75, 1279-1283. https://doi.org/10.1016/j.talanta.2008.01.045

[19] Amin, A.S. (2003) Solid-Phase Spectrophotometric Determination of Trace Amounts of Vanadium Using 2,3-dichloro-6(3-carboxy-2-hydroxynaphthylazo) Quinoxaline. Spectrochemica Acta Part A, 59, 1025-1033. https://doi.org/10.1016/S1386-1425(02)00259-7

[20] Mahaveer, B.M., Jaldappa, S. and Saraswati, P.M. (2001) Spectrophotometric Determination of Vanadium(V) in Minerals, Steels, Soil and Biological Samples Using Phenothiazine Derivates. Analytical Sciences, 17, 979-984.

[21] Hu, Q., Yang, G., Huang, Z. and Yin, J. (2004) Study on Solid Phase Extraction and Spectrophotometric Determination of Vanadium with 2-(2-Quinolylazo)-5Diethylaminopheno. Bulletin of the Korean Chemical Society, 25, 263-271. https://doi.org/10.5012/bkcs.2004.25.2.263

[22] Agnihotri, N., Dass, R. and Mehta, J.R. (1999) A Highly Sensitive and Selective Spectrophotometric Determination of Vanadium(V) Using 6-Chloro-3-Hydroxy-7Methyl-2-(2-Thienyl)-4H-Chromen-4-One. Analytical Science, 15, 1261-1271.

[23] Yamane, T., Osada, Y. and Suzuki, M. (2000) Continuous Flow System for the Determination of Trace Vanadium in Natural Waters Utilizing In-Line Preconcentration/Separation Coupled with Catalytic Photometric Detection. Talanta, 45, 583-589. https://doi.org/10.1016/S0039-9140(97)00188-4

[24] Paleologos, E.K., Koupparis, M.I., Veltsistas, P.G. and Karayannis, M.I. (2001) Nonaqueous Catalytic Fluorometric Trace Determination of Vanadium Based on the Pyronine B-Hydrogen Peroxide Reaction and Flow Injection after Cloud Point Extraction. Analytical Chemistry, 73, 4428-4436. https://doi.org/10.1021/ac010395k

[25] Shiobara, T., Teshima, N., Kurihara, M., Nakano, S. and Kawashima, T. (1999) Catalytic Flow Injection Determination of Vanadium by Oxidation of N-(3-Sulfo 3,Tetramethylbenzidine Using Bromated. Talanta, 49, 1083-1090.

[26] Ni, Y. and Jin L., Chemom, (1999) Simultaneous Polarographic Chemometric Determination of Lead, Copper, Vanadium, Cadmium and Nickel. Chemometrics and Intelligent Laboratory Systems, 45, 105-111. 
https://doi.org/10.1016/S0169-7439(98)00094-X

[27] Sander, S. (1999) Simultaneous Adsorptive Stripping Voltammetric Determination of Molybdenum(VI), Uranium(VI), Vanadium(V), and Antimony(III). Analytica Chimica Acta, 394, 81-87. https://doi.org/10.1016/S0003-2670(99)00218-4

[28] Pearson, D. (1976) The Chemical Analysis of Food. 7th Edition, Churchill-Livingstone, Edinburgh.

[29] AOAC (1998) Official Methods of Analysis of the Association of Official Analytical Chemists. 16th Edition, AOAC, Gaithersburg.

[30] Wann, C.C. and Jiang, S.J. (1997) Determination of Vanadium Species in Water Samples by Liquid Chromatography-Inductively Coupled Plasma Mass Spectrometry. Analytica Chimica Acta, 357, 211-217. https://doi.org/10.1016/S0003-2670(97)00570-9

[31] Wuilloud, R.G., Salonia, J.A., Gasquez, J.A., Olsina, R.A. and Martinez, L.D. (2000) Online Pre-Concentration System for Vanadium Determination in Drinking Water Using Flow Injection-Inductively Coupled Plasma Atomic Emission Spectrometry. Analytica Chimica Acta, 420, 72-78. https://doi.org/10.1016/S0003-2670(00)01010-2

[32] Wuilloud, R.G., Salonia, J.A., Olsina, R.A. and Martinez, L.D. (2000) Determination of Vanadium(V) in Drinking Water by Flow Injection and Pre-Concentration in a Knotted Reactor by Inductively Coupled Plasma Optical Emission Spectrometry with Ultrasonic Nebulization. Spectrochimica Acta Part B, 55, 671-678. https://doi.org/10.1016/S0584-8547(00)00215-9

[33] Hirata, S., Umezaki, Y. and Ikeda, M. (1986) Determination of Chromium(III), Titanium, Vanadium, Iron(III), and Aluminum by Inductively Coupled Plasma Atomic Emission Spectrometry with an On-Line Preconcentrating Ion-Exchange Column. Analytical Chemistry, 58, 2602-2610.

[34] Sanchez-Vinas, M., Bagur, G.M., Gasquez, D., Camino, M. and Romero, R.J. (1999) Determination of Tin, Vanadium, Iron, and Molybdenum in Various Matrices by Atomic Absorption Spectrometry Using a Simultaneous Liquid-Liquid Extraction Procedure. Journal of Analytical Toxicology, 23, 108-116. https://doi.org/10.1093/jat/23.2.108

[35] Kawakubo, S., Ogihara, K. and Iwatsuki, M. (1995) Catalytic Spectrofluorimetric Determination of Vanadium Using Oxidation of o-Phenylenediamine with Bromate in the Presence of Gallic Acid. Analyst, 120, 2719-2725. https://doi.org/10.1039/an9952002719

[36] Gao, J., Zhang, X., Zhao, B., Yang, W., Zhao, Y., Teng, X. and Kang, J. (1999) Catalytic Quenching Spectrofluorimetric Determination of Trace Amounts of Vana$\operatorname{dium}(\mathrm{V})$ Based on Its Catalytic Effect on the Azomethine-H-Bromate Reaction. Analytical Letters, 32, 2127-2139. https://doi.org/10.1080/00032719908542958

[37] Paleologos, E.K., Giokas, D.L., Tzouwara-Karayanni, S.M. and Karayannis, M.I. (2002) Spectrofluorometric Determination of Vanadium Based on the Formation of a Ternary Complex between Vanadium, Peroxides, and 2- $\alpha$-Pyridylthioquinaldinamide. Application to the Determination of Hydrogen Peroxide and Peroxy Acids. Analytical Chemistry, 74, 100-106. https://doi.org/10.1021/ac0108008

[38] Grasesand, F. and Genestar, C. (1983) Some Pyrazolines and Isoxazolines as Fluorimetric Reagents. Kenetic-Fluorimetric Determination of Vanadium. Analytica Chimica Acta, 148, 245-255. https://doi.org/10.1016/S0003-2670(00)85169-7

[39] Salinas, F., Garcia-Saccbez, F., Grpses, F. and Genestar, C. (1980) Determination of $\mathrm{V}(\mathrm{V})$ by Means of 1-Amino-4-Hydroxynthraquince by a Kinetic Spectrofluorime- 
tric Method. Analytical Letters, 13, 473-485. https://doi.org/10.1080/00032718008059803

[40] Garcia, A.M., Fermin, C., Barrerot, A. and Ceba, M.R. (1996) Sensitive Spectrofluorometric Determination of Vanadium with Sodium 1, 2-Dihydroxyanthraquinone-3Sulfonate in Cationic Micellar Medium. Analytical Sciences, 12, 647.

[41] Salinas, F., Peiia, A.M., Pefia, F.M. and Merds, I.D. (1988) Spectrofluorimetric Determination of Vanadium(V) in Petroleum Crudes and Basic Slag with Nuclear Fast Red. Analyst, 113, 987-990. https://doi.org/10.1039/AN9881300987

[42] Bing, L. and Lanhua, C. (1997) Catalytic Fluorimetric Determination of Trace Vanadium by Oxidative Discoloration of Safranin T. Chinese Journal of Analytical Chemistry, 6, 121-128.

[43] Pal, B.K. and Ali, S.K.M. (2000) Spectrofluorimetric Determination of Vanadium at Ultra-Trace Levels. Journal of Chem. Technology, 7, 82-88.

[44] Jie, N., Zhang, Q., Wei, Y. and Jiang, Q. (2002) Study on the Catalytic Determination of Vanadium(V) Using the Rhodamine 6G-Periodate Redox Reaction and Its Analytical Application. Microchimica Acta, 140, 103-107. https://doi.org/10.1007/s006040200073

[45] Feng, N.-C., Xu, B.-X., Bai, Z.-P. and Fang, Y.-Z. (1994) Determination of Trace Amounts of Vanadium with a New Reagent [1-(3-methoxysalicylidene-amino)-8hydroxy-3,6-naphthalene Disulfonic Acid, Disodium Salt] by Fluorescence Quenching Method. Talanta, 41, 1841-1844. https://doi.org/10.1016/0039-9140(94)00125-1

[46] Sanchez, F.G., Navas, A., Santiago, M. and Grases, F. (1981) Kinetic Fluorimetric Determination of Traces of Vanadium(V) by Means of a Catalysed Autoxidation Process. Talanta, 28, 833-840. https://doi.org/10.1016/0039-9140(81)80025-2

[47] Wu, Z.Q., et al. (1996) Catalytic Fluorimetic Determination of Trace Vanadium(V) with Salicylidene-7-Amino-8-Hydroxy-5-Sulfoquinoline. Chinese Journal of Analytical Chemistry, 4, 326-334.

[48] Ming, H. and Hua, Z.Q. (2001) Study on Fluorescence Enhancing Reaction of Vanadium(V)-Morin-Cetyltrimethylammonium Bromide System and Its Analytical Application. Analytical Laboratory, 3, 273-381.

[49] Yu, Y., Nie, R.H., Huang, J.F. and Xiong, P.P. (1995) Application of Multi-Object Simplex Method in Catalytic Fluorimetric Determination of Trace Vanadium(V) Using Alizarin Red. Chinese Journal of Analytical Chemistry, 8, 220-226.

[50] Yu, Y., Hong, C.H., Huang, J.F. and Wang, R.Q. (1996) Catalytic Fluorimetric Determination of Trace Vanadium(V) Using Nihydrin-7-Amino-8-Hydroxy-5-SulfoQuinoline and Its Kinetic Reaction Mechanism. Chinese Journal of Analytical Chemistry, 9, 395-402.

[51] Xuan, Z., Qi-liang, D., Jin-zhang, G., Wu, Y., Yan-chun, I. and Jing-wan, K. (1999) Catalytic Quenching Spectrofluorimetric Determination of Trace Amounts of Vanadium(V). Journal of Fuzhou University (Natural Sciences Edition), S1, 117-124.

[52] Guohua, W., Yuxinand, Z. and Huaigong, W. (1994) A Fluorometric Quenching Method for the Determination of Trace Amounts of Vanadium in the Presence of Surfactants. Analytical Laboratory, 3, 375-381.

[53] Bao, S.Y., Cheng, Y.Q. and Shi, S.X. (2003) Determination of Trace Vanadium Using Neutral Red by Catalytic Fluorimetry. Journal of Hebei University (Natural Sciences Edition), 2, 313-320.

[54] Chen, L.H. and Ge, H.Y. (2003) Catalytic Fluorimetric Determination of Trace Vanadium with Phenosafranine as Indicator. Spectroscopy and Spectral Analysis, 6, 
131-341.

[55] Bao, S.Y., Li, S.C. and Shi, S.X. (2001) Catalytic Fluorimetric Determination of Trace Vanadium Using Acridine Orange. Chinese Journal of Analytical Chemistry, 14, 175-181.

[56] Sintiago, M., Navas, A., Laserna, J.J. and Sanchez, F.G. (1982) Iron(III) as Activator for Catalytic Fluorimetric Microdetermination of V(V). Talanta, 29, 615-620. https://doi.org/10.1016/0039-9140(82)80011-8

[57] Salinas, F., Garcia-Sanche, F. and Genester, C. (1982) Fluorimetric Determination of Vanadium Based on Its Reaction with 1-Amino-4-Hydroxyanthraquinone. $\mathrm{Mi}$ crochemical Journal, 27, 26-32. https://doi.org/10.1016/0026-265X(82)90082-0

[58] Ruedas Rama, M.J., Ruiz Medina, A. and Molina Diaz, A. (2005) A Flow-Injection Renewable Surface Sensor for the Fluorimetric Determination of Vanadium(V) with Alizarin Red S. Talanta, 66, 1333-1340. https://doi.org/10.1016/j.talanta.2005.01.053

[59] Shen-guang, G.E., Jing-hua, Y., Cong-cong, Z., Yuan-na, Z., Fu-wei, W. and. Lei, G.E (2009) Current Advances of Triazine Reagents in Photometric Analysis. Metallurgical Analysis, 6, 225-231.

[60] Gao, J., Zhang, X., Yang, W. and Kang, J. (2002) Highly Sensitive Spectrofluorimetric Kinetic Determination of Ultratrace Amounts of Vanadium(V) Based on the Oxidation of 1,8-Diaminonaphthalene by Bromate. Analytica Chimica Acta, 455, 159-165. https://doi.org/10.1016/S0003-2670(01)01583-5

[61] U.S. Environmental Protection Agency (1986) Pyridine, 90-Day Sub-Chronic Oral Toxicity in Rats. Office of Solid Waste, Washington DC.

[62] Porter, H.D. (1954) The Willgerodt Reaction Applied to $\alpha$ - and $\gamma$-Alkylpyridines. Journal of American Chemical Society, 76, 127-132. https://doi.org/10.1021/ja01630a035

[63] Pal, B.K., Ahmed, M.J. and Chakrabarty, A.K. (1989) 2-( $\alpha$-Pyridyl)-Thioquinaldinamide (PTQA)-A Novel Fluorimetric Reagent in Inorganic Trace Analysis. I: The Nonextractive, Nonquenching Fluorescent Method for the Determination of Chromium(VI). Mikrochimica Acta, 97, 393-401. https://doi.org/10.1007/BF01242262

[64] Pal, B.K., Ahmed, M.J. and Chakrabarty, A.K. (1988) 2-( $\alpha$-Pyridyl)-Thioquinaldinamide: A Novel Fluorimetric Reagent in Inorganic Trace Analysis. Part 2. A Simple Selective Determination of Selenium(IV) at Ultratrace Levels. Analytica Acta, 206, 345. https://doi.org/10.1016/S0003-2670(00)80856-9

[65] Ahmed, M.J., Tazul, I.M. and Hossain, F. (2018) A Highly Sensitive and Selective Spectrofluorimetric Method for the Determination of Manganese at Nanotrace Levels in Some Real, Environmental, Biological, Soil, Food and Pharmaceutical Samples Using 2-( $\alpha$-Pyridyl)-Thioquinaldinamide. RSC Advances, 8, 5509-5522. https://doi.org/10.1039/C7RA12762F

[66] Jeffery, G.H., Bassett, J., Mendham, J. and Denney, R.C. (1994) Vogel's Textbook of Quantitative Chemical Analysis. ELBS of 5th Edition, Bath Press Ltd., London, 275-280.

[67] Mukharjee, A.K. (1970) Analytical Chemistry of Zirconium and Hafnium. Pergamon Press, New York, 12-32.

[68] Pal, B.K. and Chowdhury, B. (1984) Triazene-N-Oxides as New Type of Fluorimetric Reagents. Microchimica Acta, 11, 121-129. https://doi.org/10.1007/BF01237266

[69] Mitra, S. (2003) Sample Preparation Techniques in Analytical Chemistry. Wiley-Inter Sciences, Hoboken, 125-162. https://doi.org/10.1002/0471457817 
[70] Ojeda, C.B., Torres, A.G., Rojas, F.S. and Pavon, J.M.C. (1987) Fluorimetric Determination of Trace Amounts of Gallium in Biological Tissues. Analyst, 112, 1499-1506. https://doi.org/10.1039/AN9871201499

[71] Ahmed, M.J., Stalikas, C.D., Veltsistas, P.G., Tzouwara-Karayanni, S.M. and Karayannis, M.I. (1997) Simultaneous Spectrofluorimetric Determination of Selenium(IV) and (VI) by Flow Injection Analysis. Analyst, 122, 221-226. https://doi.org/10.1039/a606357h

[72] Pal, B.K., Ahmed, M.J. and Chakraborty, A.K. (1990) 2-( $\alpha$-Pyridyl)-Thioquinaldinamide: A Spectrofluorimetric Reagent in Inorganic Trace Analysis. Part III. Determination of Manganese in Industrial and Environmental Samples. Analyst, 115, 439-443. https://doi.org/10.1039/AN9901500439

[73] Sun, C., Yang, J.Y. and Tzeng, S.R. (1999) Rapid Determination of Molybdate in Natural Waters by Coprecipitation and Neutron Activation Analysis. Analyst, 124, 421-426. https://doi.org/10.1039/a809596e

[74] Greenberg, E.A., Clesceri, S.L. and Eaton, D.A. (1992) Standard Methods for the Examination of Water and Wastewater. 18th Edition, American Public Health Association, Washington DC, 253-268.

[75] Chambon, P., Lound, U. and Ohanian, E. (1993) WHO Guidelines for Drinking Water Quality. Recommendations, 2nd Edition, WHO, Geneva.

[76] Miura, J. (1990) Determination of Trace Amounts of Vanadium in Natural Waters and Coal Fly Ash with 2-(8-quinolylazo)-5-(dimethylamino)phenol by Reversed-Phase Liquid Chromatography-Spectrophotometry. Analytical Chemistry, 62, 1424-1432. https://doi.org/10.1021/ac00213a015

[77] Stahr, H.M. (1991) Analytical Methods in Toxicology. 3rd Edition, John Wiley and Sons, New York, 85-94.

[78] Mittal, S. and Pandey, A.K. (2014) Cerium Oxide Nanoparticles Induced Toxicity in Human Lung Cells: Role of ROS Mediated DNA Damage and Apoptosis. Bio,Med Research International, 5, 126-133. https://doi.org/10.1155/2014/891934

[79] Xuan, Z., Qi-liang, D., Jin-zhang, G., Wu, Y., Yan-chun, I. and Jing-wan, K. (1999) Catalytic Quenching Spectrofluorimetric Determination of Trace Amounts of Vana$\operatorname{dium}(\mathrm{V})$. Journal of Fuzhou University (Natural Sciences Edition), S1, 117-121.

[80] Jackson, M.L. (1965) Soil Chemical Analysis. Prentice Hall, Englewood Cliffs, 326-332.

[81] https://www.ncbi.nlm.nih.gov/pubmed/24090406

[82] Ruedas Rama, M.J., Ruiz, M.A. and Molina, D.A. (2005) Implementation Multicommutation Principle with Flow-Through Multioptosensors. Talanta, 66, 1333-1341. 